\title{
mRNA vaccine: a potential therapeutic strategy
}

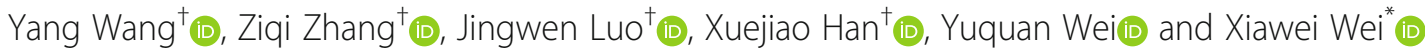

\begin{abstract}
mRNA vaccines have tremendous potential to fight against cancer and viral diseases due to superiorities in safety, efficacy and industrial production. In recent decades, we have witnessed the development of different kinds of mRNAs by sequence optimization to overcome the disadvantage of excessive mRNA immunogenicity, instability and inefficiency. Based on the immunological study, mRNA vaccines are coupled with immunologic adjuvant and various delivery strategies. Except for sequence optimization, the assistance of mRNA-delivering strategies is another method to stabilize mRNAs and improve their efficacy. The understanding of increasing the antigen reactiveness gains insight into mRNA-induced innate immunity and adaptive immunity without antibody-dependent enhancement activity. Therefore, to address the problem, scientists further exploited carrier-based mRNA vaccines (lipid-based delivery, polymer-based delivery, peptide-based delivery, virus-like replicon particle and cationic nanoemulsion), naked mRNA vaccines and dendritic cells-based mRNA vaccines. The article will discuss the molecular biology of mRNA vaccines and underlying anti-virus and anti-tumor mechanisms, with an introduction of their immunological phenomena, delivery strategies, their importance on Corona Virus Disease 2019 (COVID-19) and related clinical trials against cancer and viral diseases. Finally, we will discuss the challenge of mRNA vaccines against bacterial and parasitic diseases.
\end{abstract}

Keywords: mRNA vaccine, Self-amplifying RNA, Non-replicating mRNA, Modification, Immunogenicity, Delivery strategy, COVID-19 mRNA vaccine, Clinical trials, Antibody-dependent enhancement, Dendritic cell targeting

\section{Introduction}

A vaccine stimulates the immune response of the body's immune system to produce antibodies. Classical vaccine originates from anti-viral immunity [1]. Dating back to 1796, Edward Jenner found that healthy individuals inoculated with cowpox on the milkmaids' hands had preventative immunity against smallpox infection [2]. Multiple virus-oriented vaccines are currently used for routine vaccination, which gains significant progress in preventing and treating viral diseases. Therefore,

\footnotetext{
*Correspondence: xiaweiwei@scu.edu.cn

†Yang Wang, Ziqi Zhang, Jingwen Luo and Xuejiao Han contributed equally to this work.

Laboratory of Aging Research and Cancer Drug Target, State Key Laboratory of Biotherapy, National Clinical Research Center for Geriatrics, West China Hospital, Sichuan University, No. 17, Block 3, Southern Renmin Road, Chengdu, Sichuan 610041, PR China
}

scientists are seeking to develop effective cancer vaccines. In 2006, the FDA approved the first cancer vaccine in human history: A vaccination against cervical cancer (Gardasil). Gardasil prevents the infection of human papillomavirus (HPV) 16/18 for more than 5 years, decreasing cervical cancer incidence $[3,4]$. However, most of the cancer vaccines are under preclinical and clinical trials. Although much progress towards developing vaccines has been achieved, there still exist viral pathogens escaping the adaptive immune responses [5]. Besides, the increasing need for large-scale production and rapid development urges to develop novel vaccine approaches. Non-viral diseases, including cancer, need more vaccine-related researches to foster a novel vaccine development platform.

(c) The Author(s). 2021 Open Access This article is licensed under a Creative Commons Attribution 4.0 International License, which permits use, sharing, adaptation, distribution and reproduction in any medium or format, as long as you give appropriate credit to the original author(s) and the source, provide a link to the Creative Commons licence, and indicate if changes were made. The images or other third party material in this article are included in the article's Creative Commons licence, unless indicated otherwise in a credit line to the material. If material is not included in the article's Creative Commons licence and your intended use is not permitted by statutory regulation or exceeds the permitted use, you will need to obtain permission directly from the copyright holder. To view a copy of this licence, visit http://creativecommons.org/licenses/by/4.0/. The Creative Commons Public Domain Dedication waiver (http://creativecommons.org/publicdomain/zero/1.0/) applies to the data made available in this article, unless otherwise stated in a credit line to the data. 
mRNA vaccine is a newly developed technology with a combination of molecular biology and immunology. The technology is closely related to gene therapy. The foreign mRNAs encoding antigens are introduced into somatic cells to synthesize antigens by the expression system [6]. The synthetic antigens can induce the immune response [7]. As early as the year 1990, scientists used mRNA expression vectors to inject mRNAs into mouse somatic cells in vivo to express luciferase, beta-galactosidase and chloramphenicol acetyltransferase [8]. In 1992, Jirikowski et al. found that adding mRNAs encoding oxytocin and vasopressin in diabetes insipidus mice (genetically mutant) reversed diabetes insipidus temporarily within several hours after injection [9]. Although remarkable findings had been achieved from then on, we made no substantive progress on mRNA studies. The challenges were mRNA instability, excessive immunogenicity and lack of effective mRNA delivery system [10-13].

During these decades, further researches and the improvement of experimental techniques have made progress in the safety, efficacy and industrial production of mRNA vaccines. These advantages enable mRNA-based vaccines a priority in the treatment of tumors and viral diseases. Firstly, mRNA vaccines are safe to induce antibodies in human phase I clinical trials [14]. The explanation is that mRNA is not a replicating vector. mRNA vector has no characteristics of antibiotic resistance, genomic integration and strong immunogenic responses [15-17]. Additionally, nucleases rapidly degrade singlestranded RNA [18]. Although the degraded mRNA components trigger the immune system's excessive activation, developing an effective and safe delivery system with modified mRNA can enhance the efficacy and eliminate the side effects $[19,20]$. Next, the improved therapeutic efficacy is realized by modified mRNAs and mRNA carriers. In viral diseases, the HSV-2 (herpes simplex virus 2) nucleoside-modified mRNA vaccine decreased virus loads [21]. Mannose-modified liposomes were used to deliver mRNA into cells. The vector protected mRNA from degradation and promoted mRNA overexpression by upregulating mannose receptor (CD206) on cell surfaces [22]. So far, various forms of delivery vectors and modified mRNAs have been deeply investigated to test their therapeutic efficacy [23], especially during the COVID-19 epidemic [24-27]. Finally, manufacturing mRNA vaccines on a large scale tends to be industrialized. The mass production-scale relies on translational science, which is critical to accelerate the production speed. In vitro, the translational technology rapidly selects formulations and constructs in preclinical and clinical studies [28].

Accumulated preclinical evidences are paving the way for future clinical evaluation. A series of clinical trials have been launched continually. Based on the rapidity of manufacture, the mRNA vaccine is a potential therapeutic method. In the review, we will first introduce the classification and the molecular features of mRNA vaccines. Then, the mechanisms increasing the antigen reactiveness would be discussed. We will also focus on the underlying anti-viral and anti-tumor mechanisms of mRNA vaccines in different delivery strategies to enhance the biotherapeutic efficacy. Furthermore, we will review the mRNA vaccine-related clinical trials, their immunological phenomena, delivery strategies, their importance on COVID-19 and related clinical trials against cancer and viral diseases. Finally, we will discuss why scientists do not choose mRNA vaccines against bacterial and parasitic diseases.

\section{Molecular biology of mRNA vaccines}

\section{The classification and the structure of mRNA vaccines}

mRNA is an intermediate product from transcription to translation, containing genetic information to guide corresponding proteins' formation. The mRNA vaccine is a subtype of nucleic acid vaccines. It is divided into two categories: self-amplifying RNA (saRNA) and nonreplicating mRNA. The conventional non-replicating mRNA is composed of a cap, 5'-untranslated regions (UTR), open reading frame (ORF) encoding vaccine antigens, 3'-UTRs and poly(A) tail. Except for ORF, other structural elements are crucial for the stability of mRNA and transcriptional efficiency. Those elements are also modifiable sites to prolong mRNA half-life in vivo and limit unwanted immune responses [29]. For example, a modified non-replicating mRNA encoding influenza H10 hemagglutinin (HA) induced type-I IFN-polarized innate immunity and vaccine-specific responses [30]. Moreover, the mRNA recruits a series of transcriptional factors to the cis-regulatory $5^{\prime}$-UTRs/3'-UTRs to control the translational speed and the half-life of mRNA [31, 32]. Every element plays an essential role in stabilizing the mRNA structure, controlling the accessibility to ribosomes and influencing the translational mechanisms [33, 34]. The modification of elements applies the conventional mRNA vaccines to clinical practice.

Compared with saRNA, convention mRNA vaccines are characterized by the small size, simple structure and the inclusion of only one ORF encoding vaccine antigens. One vaccine-antigen-specific ORF alone guarantees the absence of unwanted immune responses [10]. Although these characteristics seem to be propitious to conduct the preclinical investigation, scientists need to further prolong the period and increase mRNA expression levels in vivo.

Another classification of mRNA vaccines is saRNA. The saRNA vaccine is originated from the alphavirus genome. Such a vaccine comprises one gene responsible 
for the viral RNA replication and the other transgene encoding the therapeutic antigen [35]. According to different methods of obtaining antigen expression, the selfamplifying RNA embodies DNA plasmid-based saRNA, virus-like particle delivering saRNA and in vitro transcribed saRNA (shown as Fig. 1). Firstly, DNA plasmid-based saRNA uses plasmid DNA as a carrier to transfer replicase genes and the transgene into the nucleus. After the transcription in the nucleus, the replicon RNA unit (replicase and transgene) translocates to the

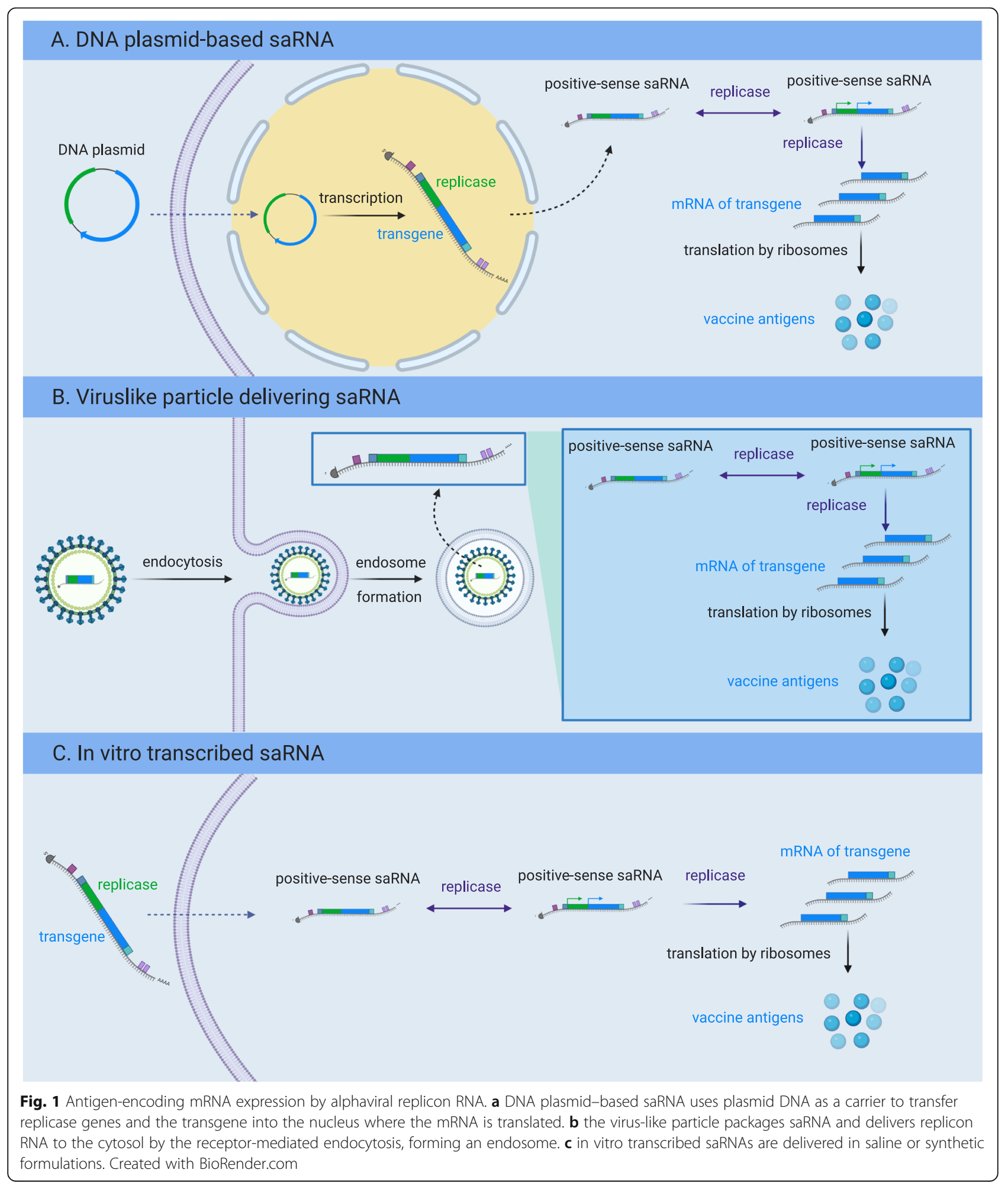


cytosol for RNA self-replication, mRNA production and the translation of vaccine antigens. The advantages are the stability, simplicity of manufacture [36] and the induction of more powerful immune responses due to the stable DNA plasmid with higher levels of antigen expression [37]. Secondly, the virus-like particle packages saRNA and delivers replicon RNA to the cytosol. The particle recognizes the receptor on the cellular membrane. The receptor-mediated endocytosis generates endosomes in the cytoplasm. The following RNA selfreplication processes to produce vaccine antigens are the same as DNA plasmid-based self-amplifying RNA. The virus-like particle has been proven to be safe and efficacious in clinical trials [38]. Finally, in vitro transcribed saRNAs are delivered in saline or synthetic formulations. Lipid nanoparticles or similar formulations are needed as vectors. If the formulation is fully synthetic, we should obey the enzymatic Current Good Manufacturing Practices (CGMP) process [39].

Based on the three kinds of saRNA structures, Beissert et al. developed an improved saRNA vaccine (trans-amplifying RNA (taRNA)) strategy to induce protective immunity (shown in Fig. 2). The taRNA relied on a bipartite vector composed of one RNA encoding the replicase and the other alphaviral RNA encoding vaccine antigens. The latter RNA did not contain the replicase to form a transreplicon with the former replicaseencoding RNA [40]. Beissert et al. used influenza hemagglutinin antigen-encoding RNA as an antigen RNA. A nanogram dose (50 ng) could elicit neutralizing antibodies and induce protective immune responses [40]. This novel taRNA excels at safety, manufacturability and ease of optimization. As for safety, the alphaviral RNA encoding vaccine antigens is separated from the whole. The separation refrains the saRNA from expressing viral glycoprotein, which helps saRNA transfer into other cells. Concerning manufacturability, long RNA transcripts do not limit the scaled-up production any more in taRNA, because the taRNA strategy shortens RNA lengths. Finally, ease of optimization can be realized by nucleoside modifications, codon optimization and stabilizing sequences [40]. Overall, the taRNA vaccine is a supreme strategy than conventional non-replicating mRNA vaccines.

\section{Eliminating immunogenicity of mRNA}

Synthesizing mRNA by in vitro transcription (IVT) is not expensive [41]. However, the most challenging problem encountered by IVT mRNA is its immunogenicity. Exogenous IVT mRNAs are recognized by retinoic acidinducible gene I (RIG-I) receptors, initiating innate immune responses [42]. IVT mRNA can activate immune cells and produce Toll-like receptor-mediated inflammation. The U-rich sequence of mRNA is a key element to activate Toll-like receptors [43]. By shortening the Urich sequence, Thess et al. believe that it is a possible method to avoid mRNA immunogenicity [44].

Modifying nucleotides chemically, adding poly (A) tails and optimization mRNA with GC-rich sequence are effective methods to reduce the immunogenicity of mRNAs. First, nucleotide chemical modification does not influence the translation of mRNAs. Numerous scientists replaced cytidine with 5-methylcytidine (m5C), replaced uridine with 5 -methyluridine $(\mathrm{m} 5 \mathrm{U})$, replaced adenosine with N1-methyladenosine $(\mathrm{m} 1 \mathrm{~A})$ and N6methyladenosine (m6A), 2-thiouridine (s2U), 5methoxyuridine $(5 \mathrm{moU})$, pseudouridine $(\psi)$ and N1methylpseudouridine $(\mathrm{m} 1 \psi)$ [45]. Among them, m5C and $\psi$ are preferable in base-pair modifications because they simultaneously reduce the immunogenicity and

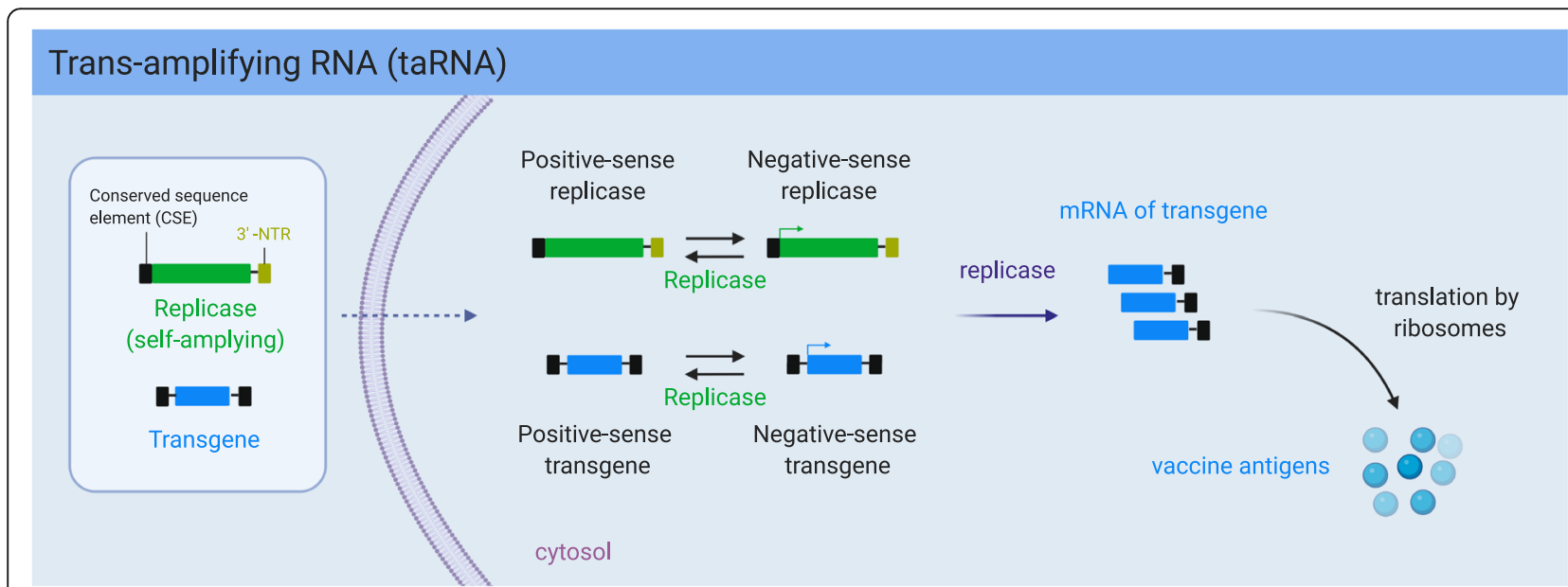

Fig. 2 Trans-amplifying RNA (taRNA) The replicase transcribes a negative strand RNA with the $3^{\prime}$-nontranslated region (NTR). In turn, it uses the negative strand RNA as a template to transcribe a positive strand RNA from the 5'-NTR region. A promoter (arrow) initiates transcription into mRNA. Vaccine antigens come from the mRNA, which is mediated by cytoplasmic ribosomes. Created with BioRender.com 
enhance the translation efficiency. Next, adding poly (A) tails decreases $U$ content and shields mRNA in the sequence, thus lowering the mRNA immunogenicity [46]. Then, CureVac and Acuitas Therapeutics delivered erythropoietin (EPO)-encoding mRNA, which has rich GC codons, to pigs with lipid nanoparticles (LNPs). Their results indicated EPO-related responses were elicited without immunogenicity [44]. However, scientists should also consider the low efficacy of protein expression caused by excessive GC content.

Followed by IVT, mRNA purification are essential to eliminate immunogenicity [47]. The purification includes high performance liquid chromatography (HPLC), anion exchange chromatography, affinity chromatography and size exclusion columns, aiming at removing truncated transcripts $[45,48]$. A good illustration is that Pardi et al. designed HPLC purified and $\mathrm{m} 1 \psi$ modified mRNAs encoding anti-HIV-1 antibody and delivered the mRNA with LNP. The results showed that the systematically administered mRNA-LNP expressed protective antibodies, helping mice get rid of HIV-1 infection [49].

The stability of mRNA vaccines by sequence optimization The mRNA is vulnerable to degradation. Stabilizing the mRNA existence will guarantee the expression effect. Multiple factors are influencing their expression and stability in cells. For example, $5^{\prime}$-UTR/3' -UTR around the ORF increases the half-life and the expression levels of vaccine mRNA [50]. 5' cap modified with locked nucleic acid (LNA)-modified dinucleotide stabilizes the mRNA. The m(7(LNA))G[5']ppp[5']G 3 cap analogue increases the translational efficacy [51]. Apart from various modification forms of $5^{\prime}$ cap, like 7-methylguanosine [52], capping the mRNA at the $5^{\prime}$ terminus with enzymes is more effective than various forms of cap analogs [53, 54]. The poly(A) tail is another mRNA-stabilizing element. Deleting the poly $(\mathrm{A})$ site from mRNA makes mRNA unstable, compared with the intact gene [55]. It is reported that removing poly $(\mathrm{A})$ with polynucleotide phosphorylase reduced the size of polysomes, the rate of peptide elongation and the number of translational rounds, respectively [56]. Therefore, the poly(A) tail is essential to maintain the stability of mRNA and successful translation [57]. Furthermore, selecting modified nucleotides and synonymous nucleotides to replace codons is another method. Although synonymous codons are unable to change the sequence of amino acids, those changes increase the mRNA stability. Sometimes, they affect the mRNA secondary structure and posttranslational modifications [58]. Additionally, increasing G:C proportion of the mRNA strengthens the mRNA stability [59]. Overall, 5'-UTR/3'-UTR, 5' cap, the poly(A) tail, rare codon and $\mathrm{G}: \mathrm{C}$ proportion are all optimizable sites for strengthening the mRNA stability.
As mentioned above, replacing the mRNA sequence with rare codons and introducing modified nucleotides are likely to change the mRNA structure, the translational accuracy [60] and the protein-folding mechinery [61]. These changes further influence the type, intensity and specificity of immune responses.

\section{Mechanisms of mRNA vaccine-mediated immunotherapy}

Since optimized mRNAs are continually existing in the cytosol, mRNA vaccines are being applied in diseaserelated immunotherapy. mRNAs are translated into corresponding antigens after being inoculated into host cells, imitating virus-infection-like humoral immunity and cellular immunity $[62,63]$. The nature of the corresponding antigens is an immune response-inducing antigen. The mRNA vaccine enhances the host's anti-virus and anti-tumor effects by increasing $\mathrm{T}$ cells' antigen reactiveness.

\section{Increasing the antigen reactiveness}

Some heterologous genes' expression products affect immune cells directly, promoting the growth and proliferation of immune cells. Hence, they can enhance the host's anti-tumor and anti-viral ability. A good illustration is that scientists used ovalbumin (OVA) to transfect into tumor cells. Tateshita et al. regarded lipoplex-type mRNA as a vector to deliver unstable mRNA (in serumcontaining medium) into bone marrow-derived dendritic cells (BMDCs). The results showed prominent OVAspecific cytotoxic $\mathrm{T}$ lymphocyte activity in vivo and antitumor effect by expressing the OVA protein [64]. Similarly, as for viral diseases, Joe et al. investigated whether intranodally administrated nucleoprotein mRNA vaccine could induce protective immunity. Nucleoprotein is a conserved virus protein. They found that the nucleoprotein mRNA vaccine lowered immune cells' infiltration and increased the infiltrating proportion of monocytes, MHC $\mathrm{II}^{+}$alveolar macrophages and T cells. The intensive response was protective [65]. The spike protein of severe acute respiratory syndrome coronavirus 2 (SARS$\mathrm{CoV}-2$ ) is prefusion-stabilized. Corbett et al. used it to produce an mRNA vaccine and assessed viral replication in nonhuman primates. The results indicated that the mRNA vaccine generated intensive SARS-CoV-2 neutralizing antibodies without any pathologic changes in the lungs [25].

Tumor cells may evade and survive through various mechanisms when encountering immune cells [66]. For example, MHC-I is expressed on the surface of nucleated cells. The molecule presents epitopes of the antigens processed by antigen-presenting cells (APCs) for the recognition of other immune cells. As for tumors, presenting tumor-associated antigens (TAAs) to $\mathrm{T}$ cell 
receptors (TCRs) by MHC-I is an initiator of $\mathrm{CD}^{+}$-cytotoxic-T-lymphocyte (CTL) activation [67]. Therefore, the down-regulation of MHC-I on tumor cell surfaces helps tumor escape from the immunologic surveillance [68]. To improve the tumor's immunogenicity, introducing mRNA encoding MHC-I and TAA $[69,70]$ into tumor cells enabled the up-regulation of MHC-I. Thus, immune cells recognized tumor cells and pathogens rapidly, which improved the therapeutic efficacy of mRNA vaccines by enhancing viral/tumoral immunogenicity.

In mRNA vaccination, B cell immunity is an important immunological component after the dendritic cell (DC) maturation and the induction of robust $\mathrm{T}$ cell responses [71]. Most of the antiviral vaccines induce protective antibody responses. Antibodies are produced from germinal centers (GCs) in B cell follicles of secondary lymphoid organs. Before maturation, B cells experience proliferation, somatic mutation and selection of highaffinity mutants in GCs with the help of $\mathrm{T}$ cells [72]. Subsequently, B cells receive intact antigens presented by DCs to generate an antibody response [73]. If the antigen availability is sustained during germinal center initiation, antibody responses to vaccination would be robust. Robust antibody responses drive the increase of antibody titers and B cell/T follicular helper cell responses in the germinal center [74]. T follicular helper cells must be activated to promote sustained neutralizing antibody responses. Viral infections reply on this cellular immunity because viruses can evade humoral immunity. This process strengthens the potency of intramuscularly and intradermally delivered mRNA-LNP vaccines [23, 75]. For example, mRNA vaccine encoding RSV fusion (F) caused potent $\mathrm{T}$ cell and $\mathrm{B}$ cell immune responses in mice [76]. The subcutaneous administration of influenza antigen-encoding mRNA complexed with LNPs and PEI generated $\mathrm{T}$ cell and $\mathrm{B}$ cell responses in mice [77, 78]. The interaction of GCs and T follicular helper cells remains to be elucidated. Understanding this process will facilitate future vaccine design.

\section{Induced innate immunity and adaptive immunity}

mRNA vaccines induce innate immunity and adaptive immunity. Innate immunity is the first defensive line against non-self substances. The pathogen-associated molecular patterns (PAMPs) on mRNA is recognized by pattern recognition receptors (PRRs) on cell surfaces [79]. The binding of the ligand-receptor complex transduces signals into cells, further initiating a series of cascades of signaling pathways. Activated second messagers translocate to the nucleus as transcriptional factors, recruiting different trans-acting factors to promote the expression of proinflammatory cytokines and chemokines [80, 81]. Before the activation of adaptive immunity, it is essential to understand how cells sense non-self
mRNA and initiate cascades of signaling pathways by the interaction of mRNA, PRRs and PAMPs. There are two kinds of PRRs that sense extracellular and intracellular PAMPs, respectively [82]. On the one hand, the recognition of RNA inside the endosome is Toll-likereceptor (TLR)-mediated [83]. Accumulated evidence shows that the TLR-MyD88-NFKB signaling pathway is regularly involved in PAMP recognition [83]. TLR-3 recognizes and binds to double-stranded RNA (dsRNA), modulating the activation of type I interferon (IFN) pathway and the secretion of cytokines and chemokines [84]. Alternatively, as a PAMP, single-stranded RNA (ssRNA) is combined with TLR-7 to activate nitric oxide synthase (NOS2) [85]. On the other hand, the cytosolic non-self RNA is recognized by RIG-I receptors [42], nucleotide oligomerization domain (NOD)-like receptors (NLRs) [86], RNA-dependent protein kinase receptor (PKR) [87] and oligoadenylate synthetase (OAS) receptors [88]. Activated RIG-I recognizes a novel long noncoding RNA (Lnczc3h7a), together with TRIM25 (an E3 ubiquitin ligase that mediates K63-linked ubiquitination of RIG-I), to strengthen RIG-I-mediated antiviral innate immunity [89]. Another RNA sensor (PKR) regulates the transcription factor IRF1, preventing the translational process from shutting down to fight against the virus [86]. Together, whatever RNA sensor is, RNA-induced PRRs contribute to type I IFN production. IFN- $\gamma$ positively promotes the activation of PKP and the phosphorylation of eIF2 $\alpha$.

Nevertheless, at the same time, a negative feedback loop is formed to restrict the production of IFN- $\gamma$, affecting mRNA translation and posttranslational modifications [90]. Moreover, the overexpression of IFN promotes the binding of OAS and dsRNA for generating RNase L to degrade non-self RNA. Therefore, the optimized mRNA vaccines should meet the requirement that the innate immunity is fully activated to initiate the adaptive immunity. mRNA sequence designers should avoid excessive activation of the innate immunity that hinders mRNA translation.

\section{Immunological adjuvants}

Co-administration of mRNA vaccines and their corresponding adjuvants can enhance the body's immune response to antigens. Immunobiologically, the adjuvant is supplemented to enhance immunogenicity, increase titers of antibodies, alter antibody types and strengthen delayed hypersensitivities. However, the adjuvant mechanism is not completely clear and the mechanism of different adjuvant action is different. First, saRNA delivered by a cationic nanoemulsion (CNE) delivery system based on Novartis's proprietary adjuvant MF59 is welltolerated and immunogenic [91, 92]. TriMix is another mRNA adjuvant that includes three immune-modulatory 
molecules (active TLR-4, CD40 ligand and CD70). TriMix mRNA incorporated with other tumor-antigen mRNAs are administrated into stage III or IV melanoma patients. It showed augmented immunity and achieved a durable clinical relief [93]. In multiple vaccine studies, TriMix is involved in promoting DC maturation and CTL activation [94]. The preclinical studies have made TriMix towards clinical trials [95-97]. A third adjuvant is the RNActive (CureVac AG) vaccine platform containing both free and protamine-complexed mRNA. The vaccine combines properties of adequate antigen expression and autologous self-immune-stimulation well. The technique relies on the type of mRNA carrier, because it is responsible for providing adjuvant activity. Protamine is a crucial delivery element which has intrinsic adjuvanticity. It contributes to expressing vaccine antigens and stimulating innate immunity by the activation of TLR-7 [98]. In the study, inoculating the self-adjuvanted vaccine indicated a durable $\mathrm{T}$ cell-mediated immunity. In other words, the RNActive vaccine activates $\mathrm{T}$ cell-based immunity. $\mathrm{T}$ cells are transformed into antigen-specific memory $\mathrm{T}$ cells for the recognition of non-self antigens [99]. In human clinical trials, RNActive vaccines have good tolerability and immunogenicity [98, 100, 101]. RNAdjuvant is an innovative adjuvant whose nature is a 547-nucleotide non-coding ssRNA. A cationic peptide can stabilize poly U repeats in the ssRNA [102]. Mechanically, the RNAdjuvant induces neutralizing antibodies by TLR7-dependent activation of markers on DCs and the production of IFN-I. In MyD88-/-Cardif-/- mice, the lack of TLR and RIG-I-like helicase caused a reduced adjuvant effect [102]. In cancer patients, the RNAdjuvant upregulated CD80, CD86 and HLA-DR in circulating DCs, which promoted $\mathrm{CD} 4^{+} \mathrm{T}$ cell activation [103].

mRNA vaccines elicit humoral immune responses without antibody-dependent enhancement (ADE) activity

$\mathrm{ADE}$ is a phenomenon that antibody protection against other viruses can deteriorate the infection and trigger harmful immunopathology [104]. Cross-reactive antibodies against the epitope on the $\mathrm{E}$ protein of zika virus deteriorate the dengue virus infection [105]. The phenomena should also be taken into consideration in developing coronavirus vaccines [106]. Therefore, ADE has been a significant concern for vaccine development.

Currently, Laczko et al. designed nucleoside-modified mRNA vaccines encapsulated with LNPs (mRNA-LNP). The mRNA encodes the full-length SARS-CoV-2 spike protein. The SARS-CoV-2 mRNA vaccine induced high levels of $\mathrm{S}$ protein-specific IgG. To further investigate whether or not the mRNA vaccine could elicit antibodymediated ADE, they used HEK293T cells expressing mouse FcgR1. The results indicated no SARS-CoV-2 $\mathrm{ADE}$ by testing the mRNA-vaccinated mouse sera [107].
However, most animal models and in vitro models seldom predict ADE. One reason is that antibody-mediated mechanisms are the same. Another is that designing animal models depends on understanding how antiviral responses become harmful in humans [104]. Hence, we need more studies to define the clinical correlation with protective immunity. Moreover, we should carefully analyze the safety of mRNA vaccine in humans because $\mathrm{ADE}$ of diseases cannot be predicted after administrating antibodies and vaccination.

\section{Delivery strategies of mRNA vaccines}

Due to the instability of mRNA vaccines, the introduction of mRNA vaccines needs some carriers' assistance. Hence, scientists have developed lipid-based delivery, polymer-based delivery, peptide-based delivery, viruslike replicon particle delivery and cationic nanoemulsion delivery. Furthermore, the naked mRNA vaccine can also be directly injected into cells. To date, DC-based mRNA vaccines are newly developed to elicit adaptive immunity. This part will introduce the delivery strategies of mRNA vaccines from three aspects (every delivery method is shown in Fig. 3).

\section{Carrier-based mRNA vaccines \\ Lipid-based delivery}

Lipid nanoparticles (LNPs) have been widely used as carriers to deliver mRNAs [27, 108, 109]. The first conducted clinical trial of mRNA vaccines is LNP-delivered. LNPs are mature negatively-charged nucleic acid delivery platforms characterized as ionizable amino lipids, polyethylene glycol, phospholipids and cholesterol. The essential ionizable amino lipids facilitate mRNA to escape from the endosome by interacting with ionizable amino lipids and the endosomal membrane [110]. Polyethylene glycol is another essential component to prolong LNP circulation time because it spatially hinders the binding of mRNA and plasma proteins, which accelerates the clearance by reticuloendothelial (ER). Phospholipids and cholesterol can stably integrate the LNP structure [111]. To be specific, LNPs have two advantages as an mRNA vaccine vector. On the one hand, LNPs defend mRNA from degradation by enzymes from the endosome [112]. The characteristic guarantees high encapsulation efficiency [113]. On the other hand, LNPs have good biocompatibility through a series of biological processes to deliver mRNAs for expression. The first process involves the apolipoprotein E (ApoE)-low density lipoprotein receptor (LDLR) pathway. This endogenous pathway is a targeting foundation for efficient delivery [113]. Then, the TLR4-mediated endocytosis takes up LNPs, forming a vesicle to fuse with endosomes [114]. After escaping endosomes, LNPs release mRNA into the cytoplasm to synthesize vaccine antigens. 


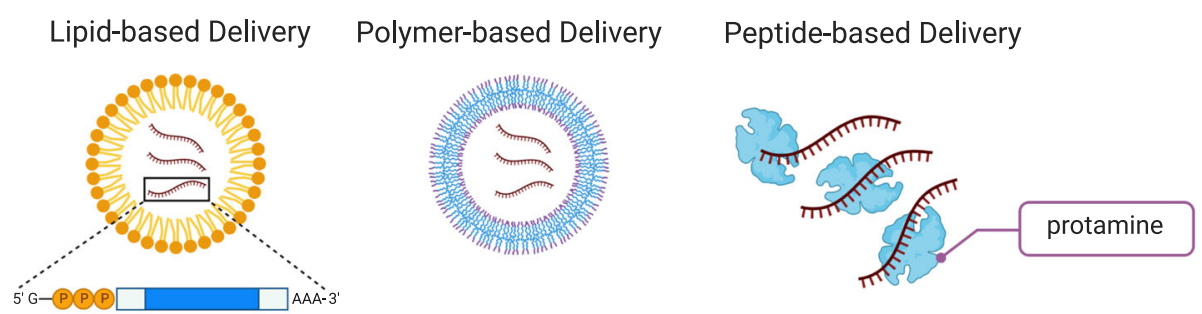

Virus-like Replicon Particle

Cationic Nanoemulsion

Naked mRNAs
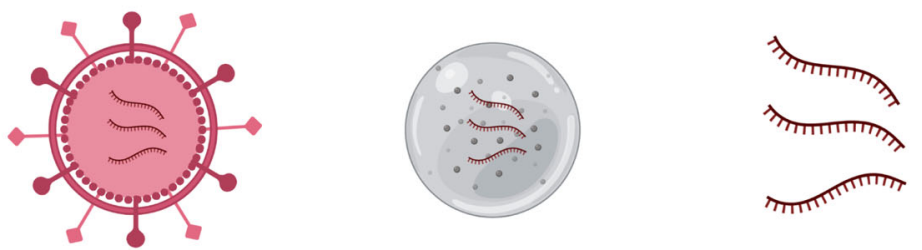

Dendritic Cell-Based mRNA Vaccines

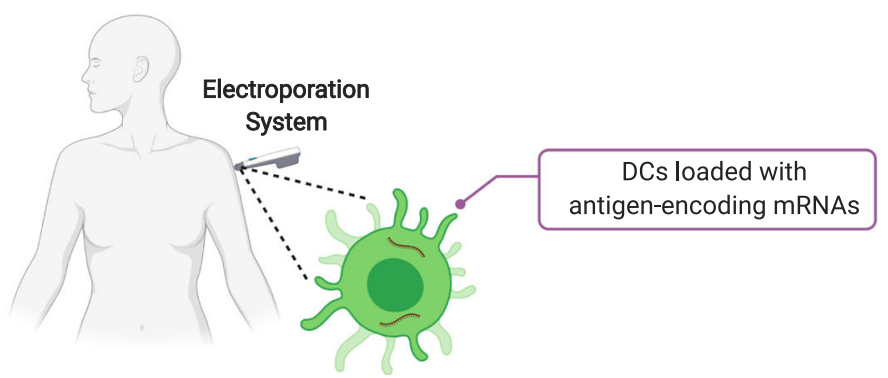

Fig. 3 Major delivery methods for mRNA vaccines Commonly used delivery methods and carrier molecules for mRNA vaccines are shown: lipidbased delivery, polyer-based delivery, peptide-based delivery, virus-like replicon particle, cationic nanoemulsion, naked mRNAs and dendritic cellbased delivery. Created with BioRender.com

The delivery efficacy of LNPs relies on multiple lipid components and lipid-related modifications. Foremost, the primary substance is cationic or ionizable lipids. Various cationic or ionizable lipids are used to deliver RNA, such as N-[1-(2,3-dioleoyloxy) propyl]-N,N,N-trimethylammonium chloride (DOTMA) [115], dilinoleylmethyl-4-dimethylaminobutyrate (Dlin-MC3DMA), N,N-Dimethyl-2,3-bis[(9Z,12Z)-octadeca-9,12dienyloxy]propan-1-amine (DLinDMA) [116], 1,2-dioleoyl-sn-glycerol-3-phosphoethanolamine (DOPE) [117], 1,2-dioleoyloxy-3-trimethylammonium propane chloride (DOTAP) [118] and $\mathrm{N}^{1}, \mathrm{~N}^{3}, \mathrm{~N}^{5}$-tris(3-(didodecylamino)propyl)benzene-1,3,5-tricarboxamide (TT3) [119]. These lipids are good delivery helpers because they are positively charged at a certain $\mathrm{pH}$. Thus the negatively charged mRNA interacts with those lipids electrostatically for delivery. Due to cellular membrane structure, mRNA-encapsulating lipids easily fuse with the targeted cellular membrane [120]. Subsequently, the endocytosis of LNPs triggers proton-pump-mediated $\mathrm{pH}$ reduction. At this $\mathrm{pH}$, the ionizable cationic lipid becomes more positively charged. Then, endogenous anionic lipids remove the cationic lipids by binding to the cationic lipids to generate a non-bilayer structure. Such a process results in disrupting the endosomal membrane and releasing mRNAs into the cytoplasm [121]. Secondly, the lipids' head and tail are important modification sites for enhancing delivery efficacy. YSK12-C4 is a pH-sensitive cationic lipid. On the one hand, the hydrophilic head of YSK12-C4 determines the acid dissociation constant (pKa), an indicator of intrahepatically distributional conditions and the endosomal escape. On the other hand, the hydrophilic tail is a non-pKa-dependent structure and shares similar functions with the hydrophilic head [122]. Thirdly, Anderson et al. developed an isocyanidecontaining lipid library. Isocyanide is a linker of dihydroimidazole. They added di-hydroimidazole to LNPs for the optimization of mRNA delivery. Consistently, they added the STING (stimulator of interferon genes) agonist to LNPs for internalization. The adjuvant stimulation increases the mRNA efficiency. Additionally, they used LNPs to deliver antigen-specific mRNA vaccines in 
several mouse models for vaccination. The results showed an increased survival rate [123].

The administration methods determine the distribution and expression kinetics of lipid-based mRNA vaccines in vivo. Local delivery is realized by subcutaneous (SC) administration, intramuscular (IM) administration, intradermal (ID) administration and intranodal (IN) administration. Scientists applied these methods to APCs and other immune cells, eliciting locally strong and long-lasting immune responses. So local delivery is used to initiate the stimulatory reaction in the small area. For example, the lipidpolymer-RNA lipopolyplexes (LPRs) containing a triantenna of $\alpha$-d-mannopyranoside (triMN-LPR) were administrated intradermally (ID) to $\mathrm{C} 57 \mathrm{BL} / 6$ mice. The triMN-LPR increased the local inflammatory responses several days later and recruited the activated DCs to the lymph nodes around the intradermal injection site. When injecting triMN-LPR encapsulating vaccine antigens to tumor-bearing mouse models intradermally, Moignic et al. found a more robust stimulatory immune response to fight against cancer [124]. Another example is that mannosylated LNPs delivering influenza (hemagglutinin) encoded saRNA vaccine generated faster antigen-specific $\mathrm{CD} 8^{+} \mathrm{T}$ cell responses by intradermal administration [125]. Subcutaneous administration facilitated the PEGylated LNPs to be uptaken by the DCs in the lymph nodes and allowed the rapid release of mRNA vaccines after cellular internalization of LNPs [126]. Intravenous (IV) administration is a kind of systematic delivery. Compared with local delivery, intravenously administered mRNA antigen vaccines generate extensive and effective immunity [127]. IV administration causes the accumulation of mRNA-LNPs in the liver, resulting in the tremendous translational activity of proteins and the productive protein-synthesizing activity [128]. Immunologically, intravenously administered LNPs encapsulating mRNA antigen vaccines can mature DCs and activate antigen-specific $\mathrm{T}$ cells both in vivo and in vitro. When scientists intravenously immunized mice with OVA-mRNA-encapsulating LNPS, mice with lymphoma were presented with the inhibition of tumor growth and the recovery of abnormal hemogram [129]. Therefore, the IV administration of LNPs is commonly used in systematic diseases, like hematological diseases.

In short, the LNP is currently a potential mRNAdelivering candidate for good biocompatibility, high delivering efficacy and so on. Except for the above preclinical investigation, phase I (NCT04064905) and phase II clinical trials (NCT03897881) are undergoing for evaluating LNP-based mRNA antigen vaccines.

\section{Polymer-based delivery}

Polymeric materials are less clinically investigated as ionizable lipids do. However, they coat mRNA without suffering from degradation and promote protein expression. The disadvantages of polymeric materials are polydispersity and the clearance of large molecules [130]. To improve the therapeutic effect, scientists have added lipid chains, expand branch structures and construct biodegradation-promoting domains [131-133].

The classification of polymers contains the cationic polymer and the anionic polymer. As for the cationic polymer, polyethylenimine (PEI) [134], polyamidoamine (PAMAM) dendrimer [135] and polysaccharide [136] are the three members. Since saRNA is sensitive to the RNase and is taken up inefficiently by DCs, condensing mRNA into the PEI-polyplex vehicle tackles the problem. An mRNA encoding hemagglutinin of influenza virus and nucleocapsid are both coated with the PEIpolyplex. The cytosolic complex facilitates the mRNA translation and induces both humoral and cellular responses [78]. In another study, the polymer-based intranasal mRNA vaccination system is designed to overcome the difficulty that the nasal epithelium serves as a barrier to hinder delivering antigens to nasal associated lymphoid tissue (NALT). The cyclodextrinpolyethylenimine $2 \mathrm{k}$ conjugate (CP $2 \mathrm{k}$ ) with HIV gp120 mRNA undoes tight junctions for paracellular delivery. Both the paracellular delivery and intracellular delivery can extend the residential time in the nose and initiate immense anti-HIV responses by producing cytokines and a balanced Th1/Th2/Th17 type [137]. Next, the dendrimer is a potential delivery vector because it has multiple functional groups with high tolerability. PAMA $\mathrm{M}$ dendritic polymers with $\mathrm{NH}_{2}$ and $\mathrm{OH}$ end functionalities respectively enter A549 human lung epithelial carcinoma cells faster than hyperbranched polymers [138]. PAMAM dendrimers were once used to construct antigen-encoding saRNA to protect mice from Toxoplasma gondii, Ebola and H1N1 influenza [139]. Taken mice with Zika virus for example, premembrane (prM)and envelope (E)-encoding saRNA with dendrimer formulation enhanced IgG concentration and induced $\mathrm{CD}^{+} \mathrm{T}$ cell-dominating responses [140]. Subsequently, Shi et al. used PAMAM (generation 0) dendrimer complexed with ceramide-PEG and poly(lactic-co-glycolic acid) (PLGA) to transfect phosphatase and tensin homo$\log$ (PTEN) mRNA for the restoration of tumor-growth suppression [141]. However, due to the spatial conformation of PAMAM, the biodegradation rate is limited, resulting in toxic accumulation. Hence, such a limitation hinders clinical development. Finally, chitosan is a polysaccharide substance involved in nanoparticulate delivery vehicles (nanogel-alginate (NGA)). Similarly, influenza virus hemagglutinin- and nucleoprotein- 
encoding mRNA are delivered to DCs by the chitosanbased nanoparticle. The vector promoted the successful translation of the two foreign antigen genes [77]. The delivery system favors the naked RNA passing through the cellular membrane and surviving in the biological condition.

Although cationic polymers are the dominant material, anionic ones are also sometimes used to deliver. The most commonly used anionic molecule is poly D, Llactide-co-glycolide. Since the negatively charged mRNA is uneasy to be delivered by anionic polymers, the addition of cationic lipid in a PGLA complex would assist in establishing an efficient RNA-encapsulating system [142]. In recent years, PLGA-incorporating nanoparticles coated with LNPs have validated its delivery efficiency for up to $80 \%$. The complex system rapidly induced the protein translation, reaching a peak in a short time and vanishing after $48 \mathrm{~h}$. The mRNA characteristic is in accordance with such a phenomenon [143]. Consistently, researches from Sharifnia et al. [144] and Zhao et al. [145] both favor the advantage of the PLGA nanoparticle system. In lymphoma-bearing mouse models, lipid-assisted nanoparticles (CLAN) encapsulating ovalbumin (OVA) mRNA reduced the tumor growth rate [129].

Collectively, the polymer-based delivery system is a promising platform for its mRNA-delivering efficacy. However, the investigation is still in the early stage of preclinical trials. More problems need to be further illustrated.

\section{Peptide-based delivery}

Due to the electrostatic interaction, the negatively charged mRNA is easily delivered by the cationic peptide. The reason why peptides are positively charged is the positively charged amino groups. For example, the lysine residue and the arginine residue bring positive charges to the amino acid, enabling electronegative mRNA to adsorb onto the cationic peptide tightly [146]. The amount of loaded mRNA is positively correlated with N/P (negative/positive) ratios [147]. Additionally, an increased ratio of charged amino/ phosphate groups can increase zeta potential and minimize the particle size, increasing encapsulating efficiency [147].

Protamines are one of the cationic peptides to deliver mRNA. Two aspects make it a potential vector. On the one hand, protamines can protect mRNA from RNasemediated degradation in the serum [148]. Stitz et al. used CureVac's RNActive technology, in which the protamine-formulated RNA is an initiator of immunity. The protamine stabilized the immunogenicity at the changing temperature without affecting the antigenencoding mRNA vaccine [149]. If not the RNActive vaccine platform, the protamine-formulated RNA alone would inhibit the translational process, further affecting the vaccine efficacy [150]. The reason for it is the excessively tight combination of the protamine and mRNAs [151]. On the other hand, protamine is an adjuvant. A study demonstrated that the protamine-formulated mRNA activated DCs and monocytes, secreting TNF- $\alpha$ and IFN- $\alpha$. It also activated immune cells by the TLR-7/ TLR-8-mediated recognition of the protamineformulated mRNA. The protamine-formulated mRNA shared some structural similarities with condensed RNA in the nucleocapsids of RNA viruses [152]. Another study proved its antitumor priority over naked nucleic acid adjuvants in glioblastoma mouse models [153]. Clinically, of all the peptide-based carriers, only the protamine is undergoing evaluations [154-156].

Cationic cell-penetrating peptides (CPPs) are another kind of small peptides containing 8-30 amino acids. They are excellent delivery vehicles because they are not only equipped with low charge densities, but also able to disrupt membrane for endosomal escape. The latter reason is essential for synthesizing proteins $[6,147]$. Coolen et al. compared the three-CPP mRNA platform, namely RALA (WEARLARALARALARHLARALARALRACEA), LAH4 (KKALLALALHHLAHLALHLALALKKA) and LAH4-L1 (KKALLAHALHLLALLALHLAHALKKA). The three peptide/mRNA complexes were all introduced into DCs and generated innate immunity. Mechanically, this process was PRR-mediated and fostered adaptive immune responses. Meanwhile, the uptake process and their intracellular activities involve clathrin-mediated endocytosis and phagocytosis. Among the three, the LAH4-L1/mRNA complex showed the optimal protein expression [157]. Another investigation combined the cationic characteristic and the cell-penetrating characteristic by formulating the fused protamine-CPP protein. The fused protein delivered reporting genes to human cell lines [158].

Like polymer-based delivery, anionic peptides are also conjugated to a positively charged substance because two negatively charged substances repel each other. For example, the addition of a positively charged copolymer p(HPMA-DMAE-co-PDTEMA-co-AzEMAm) (pHDPA) is to encapsulate the OVA-mRNA. Then, the azide groups on pHDPA conjugate an anionic peptide GALA (N-WEAALAEALAEALAEHLAEALAEALEALAA-OH-

C). Such a formulated complex, as a vector, showed enhanced EGFP-mRNA transfection in RAW 246.7 macrophages and DCs. It entered DCs by sialic acid-mediated endocytosis, regardless of the maturation of DCs. Introducing GALA contributed to cell uptake and mRNA release from the endosome by integrating with the sialic acid group on the DC surface. The uptaking process is more efficient than the lipofectamine. Based on the effective transfection, the OVA-mRNA-encapsulating complex triggered prominent immune responses [159]. 


\section{Virus-like replicon particle}

Virus-like Replicon Particles (VRPs) can encapsulate antigen-encoding saRNA for delivering into the cytosol, which is like a virus-infecting manner. The viral structure proteins are synthesized in vitro, followed by encapsulating designated antigen-encoding saRNA. Some attenuated viruses maintain the ability of self-replication [160]. In multiple virus types, the enhancement of vaccine potency has been validated. Most recently, alphavirus-derived replicon RNA encoding the SARSCoV-2 spike (S) protein has been encapsulated in lipid inorganic nanoparticles (LIONs). The formulated vaccine was intramuscularly injected into mice and primates, indicating the increased level of anti-SARS-CoV$2 \mathrm{~S}$ protein IgG antibody [161]. In another study, VRP was based on an HIV-derived mRNA encoding clade C envelope glycoprotein. A VRP packaged the mRNA. In rhesus macaques, the complex provoked cellular immune responses [91]. In Venezuelan equine encephalitis VRP, the mRNA encoded two kinds of $E$ antigen of dengue virus (subviral particles [prME] and soluble E dimers [E85]). The immunization of such a VRP induced protective efficacy and E85-VRP had priority in speed and magnitude of immunity [162]. Another example is the flavivirus Kunjin based mRNA encoding granulocyte colony-stimulating factor (G-CSF). The VRP with the mRNA inhibited the growth of subcutaneous CT26 colon carcinoma and B16-OVA melanomas for half by inducing $\mathrm{CD}^{+} \mathrm{T}$ cells [163]. Lundstrom summarized viral saRNA replicon particles against viral diseases (Influenza, HIV, SIV, Ebola, Lassa, SARS-CoV, MERS-CoV, RSV, MPV, Dengue, HBV and CMV), bacterial diseases (P. falciparum, M. tuberculosis, C. botulinum, B. abortus, B. antracis, malaria, L. monocytogenes, prion and staphylococcus) and cancer, respectively [164].

Even if VRP had a therapeutic effect on viral diseases, bacterial diseases and cancer, there are two limitations. First, large-scale production has not been realized. The current time-consuming production process is limited by producing VRPs from cell lines [165]. The second one is that the complex would promote anti-vector antibodies' production, impeding the ongoing clinical trials [166]. Hence, we should lower the immunogenicity of VRPs.

\section{Cationic nanoemulsion}

Cationic Nanoemulsion (CNE) is a non-viral delivery system, which potentiates the mRNA vaccines by binding to saRNAs. One of the most essential components is the cationic lipid 1,2-dioleoyl-sn-glycero-3-phosphocholine (DOTAP). DOTAP has been utilized in clinical trials for its positive charges emulsified with the same component of the emulsion adjuvant MF59. Except for clinical use, DOTAP has priority in availability, squalene solubility and the cationic feature at a certain $\mathrm{pH}$ [92]. Cationic lipids can form a $\mathrm{pH}$-dependent nano-sized emulsion [167].

Brito et al. investigated CNE-delivered saRNA in animals (rabbit, mouse, nonhuman primate). Their saRNA encoded multiple vaccine antigens, such as the fusion (F) glycoprotein of respiratory syncytial virus (RSV), the envelope glycoprotein $\mathrm{B}(\mathrm{gB})$ of human cytomegalovirus (hCMV), a fusion protein (pp65-IE1) of phosphoprotein 65 (pp65) and immediate early protein 1 (IE-1) of hCMV and gp140 envelope glycoprotein (env) of the human immunodeficiency virus (HIV). The results demonstrated good CNE efficacy, the induction of immune responses by the adjuvant subunit and the low dose of CNE complex [92]. Consistently, it is validated that the cellular immune responses induced by saRNA-delivered CNE were more robust than that by saRNA-delivered VRP. The dose is as low as $50 \mu \mathrm{g}$, which is safe enough for immunogenicity [91]. Similarly, to fight against the venezuelan equine encephalitis virus and Zika virus, scientists developed the saRNA vaccine delivered by $\mathrm{CNE}$, both inducing robust protective immunogenicity $[168,169]$.

Based on the above preclinical studies, CNE has the potentials in human clinical evaluations.

\section{Naked mRNA vaccines}

Different from the carrier-based mRNA vaccines, naked mRNAs are delivered by directly injecting the mRNA solution. Although naked mRNAs cannot cross freely through the membrane, several studies proposed some hypotheses about its uptaking mechanism. Some researchers suggest that the uptake of naked mRNA involves DC-mediated macropinosytosis. It allows the expression of the antigen-encoding mRNA and promotes the $\mathrm{T}$ cell/DC activation. Once DCs are mature, mRNAs are diminished by DCs $[170,171]$. Without the carrier's assistance, other scientists believe that intracellular mRNAs are delivered by membrane disruption (direct penetration and permeabilization). Microinjection is a representative of direct penetration, which first began in the 1970s [172]. Permeabilization includes mechanical membrane disruption, electroporation [173], thermal membrane disruption, optoporation, biochemical membrane disruption and gated channels/valves [174].

The naked-mRNA solutions commonly used are Ringer's solution and lactated Ringer's solution [175, 176]. Both of them contain calcium, which is beneficial for mRNA uptake [177]. In several clinical trials, the two kinds of solutions were utilized. In the first trial, RNAs were dissolved in $1.0 \mathrm{mg} / \mathrm{ml}$ Ringer's solution, followed by injecting into lymph nodes [178]. Next, the $80 \mu \mathrm{g}$ mRNA vaccine was dissolved in Ringer's lactate solution for the intradermal injection on the backs of C57BL/6 
mice. Upregulated TLR7/8 drove the activation of immune cells, produced cytokines and activated innate and adaptive immunity [179].

The naked mRNA has a series of advantages. Firstly, mRNA would not be integrated into the genome. Then, cytosol-located ribosomes combine with mRNA directly, instead of DNA transfering from the nucleus to the cytosol. Thirdly, once mRNAs reach the cytosol, the translation process initiates immediately. This advantage determines the rapid immune responses after mRNA administration. Fourthly, the final location of mRNA determines the location of protein expression. Finally, mRNAs excel DNAs in decreasing toxicity and immunogenicity [174].

When it comes to its disadvantages, the vulnerability of RNase degradation may first come to our minds. However, the instability of mRNA in the serum can be compensated by changing administration methods and appropriate chemical modifications. To be specific, local delivery can avoid RNase interference from the blood, such as ID [179], IN [65], IM [76] and so on. However, most of the studies focus on the treatment of cancer.

\section{Direct injection of mRNA cancer vaccines}

Accompanied by different delivery methods (SC, IM, ID and so on), direct injection of naked mRNA is an efficient mRNA-delivering method. When it comes to cancer, intranodal delivery facilitates antigen delivery to APCs at the activated-T-cell site without recruiting DCs. A study demonstrated the optimization of intranodally administrated RNA vaccine in melanoma-bearing mice by systematically co-administrating DC-activating Fmslike tyrosine kinase 3 (FLT3) ligand, which is an adjuvant. Such a co-administration exerted improved $\mathrm{CD}^{+}$ $\mathrm{T}$ cell priming and expansion in lymphoid organs, T-cell homing to melanoma and enhanced therapeutic activity of intranodally administrated RNA [180]. Moreover, another study investigated whether intranodal co-delivery of TAA mRNA with TriMix could mature DCs and further primeTAA-specific $\mathrm{T}$ cells, finding that $\mathrm{CD} 11 \mathrm{c}^{+}$ cells in lymph nodes selectively uptaked and translated the mRNA. Meantime, the co-administration induced a stimulatory environment, generating CTL and therapeutic effects in multiple mouse models [181].

Intratumoral administration is another helpful method because it only rapidly activates tumor-related immunity, instead of introducing mRNA encoding tumorassociated antigens. Hewitt et al. found that intratumoral mouse (m)interleukin-12 mRNA therapy enhanced antitumor activity by anti-PD-L1. The regression of mIL-12uninjected distal lesions was observed. Local injection of mIL-12 is proven to be a systematic effect [182]. Consistently, Jeught et al. constructed a fusion mRNA (IL- $\beta$ and a domain of transforming growth factor $-\beta$ receptor
II). Intratumoral delivery of the mRNA had a therapeutic potential, which can be strengthened by blocking PD-1 and PD-L1 interactions [183]. As for TriMix mRNA, its intratumoral delivery produced a systematic antitumor immunity, which largely relied on tumor-infiltrating DCs (TiDC) [184].

Combining commonly used antitumor therapy with mRNA vaccines can improve vaccination outcomes. A good example is that a patient with melanoma receiving anti-PD-1 antibodies and neoepitope-encoding mRNA vaccines had higher efficacy [178]. Another illustration is adding a chemotherapy drug (cisplatin) with mRNA vaccines regressed tumors [94]. Nevertheless, the underlying mechanism remains to be elucidated.

\section{Dendritic cells-based mRNA vaccines}

$\mathrm{DC}$ is an ideal vaccine target. The primary reason is that DCs, as an APC, internalize, process and present antigens to immune cells, which generates effective adaptive immunity [185]. To be specific, such an effect results from not only the upregulation of major histocompatibility complex (MHC) molecules for combining antigens [186], co-stimulators for providing secondary signals and various cytokines for $\mathrm{T}$ cell proliferation and the formation of CTL [187], but also the secretion of chemokines for T cell recruitment [188]. As early as in the 1990s, it is reported that DCs reliably primed $\mathrm{T}$ cells in situ. $\mathrm{T}$ cells recognized the MHC molecules from the original priming DCs [189]. The following three parts will discuss representative strategies for enhancing DC Targeting and Expression in DCs, the DC mRNA vaccines in inflammatory diseases and cancers.

\section{Ex vivo and in situ loading strategy of engineered DCs with mRNA}

DCs are loaded with mRNA both ex vivo and in situ. For the ex vivo condition, immature DCs are obtained from patients' peripheral blood. After the maturation of DCs, DCs are loaded with antigen-encoding mRNA. Then, the engineered DCs are administrated back to patients.

Loading antigen-encoding mRNAs into DCs can be realized by electroporation, lipofection, nucleofection, and sonoporation ex vivo. Among them, the electroporation technique is the most frequently used [190-192]. Adding granulocyte-macrophage colony stimulating factor (GMCSF) and IL-4 to DCs is a common method for DC differentiation [193]. GM-CSF attracts immune cells and molecules to the DC site as a stimulator of immunity, promoting antigen presentation. Clinical trials (NCT03396575 and NCT00204516) involves GM-CSF/ mRNA-incorporating DC vaccines. Mature DCs express co-stimulatory molecules on their surfaces. The costimulatory molecular is one of the determinant factors 
to exert therapeutic efficacy [194]. Another factor is the ability of DCs to secret IL-12p70, which is an indicator of responses of DC vaccines [195]. This ability is strengthened by stimulating DCs with TLR ligands and proinflammatory cytokines [196].

For the in situ condition, DC transfection can be realized by directly injecting antigen-encoding mRNAs complexed with TriMix into lymph nodes. A clinical trial (NCT01684241) conducted an intranodal injection of naked mRNA in patients with advanced melanoma. TriMix showed priority in the stimulation of DCs and the enhancement of effector $\mathrm{T}$ cell functions, compared with other stimulatory cytokines [197]. NCT01066390 is the first clinical trial of TriMix-DC vaccine in patients with advanced melanoma. The combination of a checkpoint inhibitor (ipilimumab) and TriMix-DC vaccine showed satisfying results (NCT01302496).

\section{Representative strategies of enhancing DC targeting and expression in DCs}

DC targeting and mRNA expression in DCs are critical to the systematic administration of mRNA vaccines. One of the challenges is that the systematic administration of mRNA vaccines causes the aggregation of serum proteins and mRNA degradation. To overcome the difficulty, scientists developed various molecular carriers formulating mRNAs discussed above in detail. Such complexes contributed to mRNA uptake, enhance mRNA translational activities and protect it from degradation.

Another challenge is the systematically delivered biodistribution of mRNA vaccines. The issue is a huge obstacle of DC targeting after systematic administration. Pardi et al. attempted to deliver mRNA-LNPs intravenously and intraperitoneally by incorporating HPLC purified, 1-methylpseudouridine-containing mRNA and firefly luciferase into stable LNPs. The systematic delivery activated mRNA translation in the liver for several days [128]. In 2016, Kranz et al. developed an effective strategy for DC targeting after systematic administration. They believed that DCs were efficiently and precisely targeted in vivo by intravenous injection of RNAlipoplexes (RNA-LPX). RNA-LPX is optimally net charge-adjusted and functional molecular ligand-free. A positively charged lipid particle targets the lung, while a negative one targets DCs in secondary lymphoid tissues and bone marrow. The LPX protects RNA from ribonuclease degradation, facilitates its efficient uptake and promotes the expression of the encoded antigen by DC populations and macrophages. Mechanically, the IFN- $\alpha$ secreted by DCs and macrophages matures DCs in situ and activates inflammatory immunity in the early stage of viral infection. mRNA-LPXs (endogenous encoding self-antigens, mutant neo-antigens and viral antigens) induced potent effector and memory T-cell responses. As for immune responses against tumor-specific antigens, they observed apparent tumor regression in multiple mouse models [198]. After being qualified in safety evaluation in mice and nonhuman primates, mRNALPXs undergo two clinical trials in patients with triple negative breast cancer and in patients with melanoma (NCT02316457 and NCT02410733).

\section{$D C$ mRNA vaccines in viral diseases}

A well-known DC mRNA vaccine for viral diseases is the HIV-1 vaccine. Individuals infected with HIV-1 received DCs electroporated with multiple HIV-1 antigenencoding mRNA vaccines. The cellular immune responses' evaluation suggested antigen-specific $\mathrm{T}$ cell responses without clinical benefits [199-201]. Referring to electroporation, we often use it to introduce mRNA vaccines for its high mRNA delivery efficacy [202]. Mechanically, it disrupts the cellular membrane to allow the introduction of mRNA [203]. Parameters like voltage, electroporation solution, density, pulse time, cell number and RNA quantity can optimize the delivery efficiency $[64,204]$. Even if former investigations have applied the mRNA electroporation to inflammatory diseases, most of the electroporation-related mRNA vaccine studies are about cancer.

\section{$D C$ mRNA vaccines in cancer}

Based on the above features of DCs, DCs can also be utilized to deliver mRNA for cancer biotherapy, eliciting antigen-specific immune responses. In 1996, Boczkowski et al. were the first to discover that DCs pulsed with mRNA are a potential platform to elicit $\mathrm{T}$ cell responses. In this study, DCs pulsed with encoding-OVA mRNA (tumor-derived) were more effective in promoting OVAspecific CTL responses in vitro than DCs pulsed with OVA peptide. In vivo, a principal reduction of metastatic lung sites was witnessed in tumor-bearing mouse models (B16/F10.9) with poor immunogenicity and massive metastases when the mice received the OVA-mRNA vaccine [205]. Apart from OVA, other immunity-regulating proteins have been investigated in the form of mRNA. These protein-encoding mRNA served as an adjuvant to improve the efficacy of DC-based mRNA vaccines. The electroporation of DCs with mRNA encoding 4-1BB ligand (4-1BBL) [206], CD83 [207], tumour necrosis factor receptor superfamily member 4 (TNFRSF4) [208], p53 [209] and CD133 [210] all primed anti-tumor CTLs. Furthermore, proinflammatory cytokines play a role in modulating DC functions, such as GM-CSF [70], IL12p70 [211], IL-12 and IL-18 [212]. Besides, TriMix can be electroporated with the addition of mRNAs. For example, mRNA encoding Wilms' tumor gene 1 (WT1), survivin and TriMix can be electroporated [213]. In a 
study, patients received ipilimumab (IPI) and DCs electroporated with mRNA encoding TriMix and tumorassociated antigens tyrosinase (gp100, MAGE-A3 and MAGE-C2). Robust $\mathrm{CD}^{+} \mathrm{T}$ cell responses and clinical responses were witnessed in stage III/IV melanoma patients [93]. Consistently, Lint et al. found that TriMix stimulated antitumor T-cell responses [184]. The underlying mechanism is DC activation and the transition from $\mathrm{T}$ regulatory cells to $\mathrm{T}$ helper 1 (TH1)-like cells $[214,215]$. A phase IB clinical trial indicated that melanoma patients were administrated with DCs electroporated with mRNA encoding TriMix and tumorassociated antigen had prolonged progression-free survival time and tolerance [216].

\section{The COVID-19 mRNA vaccines}

We further emphasize the importance of the mRNA vaccine in the Corona Virus Disease 2019 (COVID-19). At the end of 2019, the epidemic of COVID-19 began to emerge due to the Severe Acute Respiratory Syndrome Coronavirus 2 (SARS-CoV-2) virus. Since then, multiple vaccine-developing researches had been conducted [24, $26,107,217-220]$.

\section{The efficacy of mRNA vaccines against SARS-CoV-2}

The successful preclinical investigation and clinical investigation proved the antigen-encoding mRNA vaccine to be effective and significant. In the preclinical study, the administration of mRNA encoding SARS-CoV-2 virus-like particles in mice was proven to generate a robust antiviral-like immune response [107, 218]. Consistently, Zhang et al. encapsulated mRNA encoding the receptor-binding domain (RBD) of SARS-CoV-2 with a lipid nanoparticle. They injected such a formulated vaccine into mice and nonhuman primates intramuscularly, inducing specific neutralizing antibodies and Th1-biased cellular response [219]. Subsequently, a vaccine for clinical trials was urgently developed. One of the wellknown vaccines is BNT162b1, a lipid nanoparticleformulated mRNA vaccine encoding SARS-CoV-2 spike glycoprotein RBD. Local delivery of BNT162b1 is dosedependent. The RBD-specific IgG and SARS-CoV-2 neutralizing titers increased after a second injection [221, 222]. Based on the curative effects, the phage I/II/III clinical investigation totally recruited 29,481 participants (NCT04368728).

\section{The advantages of mRNA vaccines against SARS-CoV-2 over other kinds of vaccines}

mRNA vaccines are promising candidates against SARSCoV-2, compared with other kinds of vaccines (inactivated vaccines, attenuated live vaccines, passive immunization-related vaccines, subunit vaccines, synthetic peptide vaccines, recombinant antigen vaccines,
DNA vaccines and so on). Unlike DNA vaccine, mRNA vaccinated do not enter the nucleus to participate in DNA structural transformation. So the antigenexpressing mechanism is simpler and safer. Compared with traditional vaccines, mRNA vaccine design needs virus gene sequences, instead of virus strains. The production of mRNA vaccines does not need cell culture or animal matrix, which means that the production process is simpler than protein and that the cost is lower. Meanwhile, mRNAs are a component of human sapiens cells. They can be naturally degraded with no metabolic toxicity. If SARS-CoV-2 mutates, it is much easier to modify the mRNA sequence than modify the protein structure. More importantly, the outbreak pandemic requires us to shorten the period of vaccine researches. The period of developing mRNA vaccine is shorter than inactivated vaccines, attenuated live vaccines and subunit vaccines [223].

\section{The pandemic of COVID-19 gives opportunities to mRNA} vaccine development

However, mRNA vaccines were less attractive before the twenty-first century. The reason is summarized in two aspects. On the one hand, mRNAs are not easy to be modified. They are not stable as DNA and proteins and they are vulnerable to be degraded. On the other hand, they induce more robust immune responses like virus invasion. So there are substantial safety risks to mRNA vaccines. Until 2005, Professor Katalin Kariko and Drew Weissman in the University of Pennsylvania had made a breakthrough [46]. They discovered that the key to induce mRNA-mediated immune responses was a nucleotide (uracil). It escaped the surveillance of the immune system when it was modified as pseudouracil. After solving the most crucial issue (safety), developing mRNA vaccines would become more rapid. During these years, mRNA vaccines have evolved in synthesis, modification, delivery and production. Until the epidemic of COVID19, mRNA vaccines exerted more public focus for their safety, efficacy and industrial production.

\section{Clinical trials of mRNA vaccines}

The antigen-encoding mRNA vaccine is a promising candidate for its safety, the improved therapeutic efficacy and a large scale mRNA-vaccine production. The disadvantages of mRNA are compensated by multiple delivery systems in a series of viral and cancerous preclinical studies. Therefore, developing cancer- and viral diseaseoriented mRNA vaccine is worth numerous dedication. We summarized important clinical trials of mRNA vaccines against cancer (shown as Table 1) and viral diseases (shown as Table 2) in different delivery strategies, respectively. As for tumors, most of clinical trials focus on melanoma, glioblastoma, prostate cancer and 
Table 1 Clinical trials with mRNA vaccines against cancer

\begin{tabular}{|c|c|c|c|c|}
\hline Cancer tpye & NCT number & Drug administration & Phase & Status \\
\hline \multirow{3}{*}{$\begin{array}{l}\text { Non-small Cell Lung } \\
\text { Cancer }\end{array}$} & NCT03164772 & BI 1361849 (CV9202) + Durvalumab+/-Tremelimumab & $|/| \mid$ & Recruiting \\
\hline & NCT03908671 & Personalized mRNA vaccine encoding neoantigen & - & $\begin{array}{l}\text { Not yet } \\
\text { recruiting }\end{array}$ \\
\hline & NCT02688686 & $\begin{array}{l}\text { Suppressor of cytokine signaling (SOCS) 1, MUC1 and Survivin mRNA-loaded DC + } \\
\text { cytokine-induced killer }\end{array}$ & $|/| \mid$ & Unknown \\
\hline \multirow[t]{3}{*}{ Ovarian Cancer } & NCT04163094 & W_ova1 + carboplatin/paclitaxel & I & Recruiting \\
\hline & NCT01334047 & DC-006 vaccine & $|/| \mid$ & Terminated \\
\hline & NCT01456065 & DCs loaded with TERT-mRNA and Survivin-peptide & I & Unknown \\
\hline \multirow[t]{15}{*}{ Melanoma } & NCT00204607 & mRNA+GM-CSF & $|/| \mid$ & Completed \\
\hline & NCT00978913 & DCs transfected with hTERT, survivin and p53 & I & Completed \\
\hline & NCT00940004 & Dendritic cells electroporated with mRNA encoding gp100 and tyrosinase & $|/| \mid$ & Completed \\
\hline & NCT01066390 & TriMix-DC & I & Completed \\
\hline & NCT02285413 & $\begin{array}{l}\text { DCs loaded with mRNA encoding tumor-associated antigens gp100 and tyrosinase+/ } \\
\text {-cisplatinum }\end{array}$ & $\|$ & Completed \\
\hline & NCT00204516 & mRNA coding for melanoma associated antigens+GM-CSF & $|/| \mid$ & Completed \\
\hline & NCT01278940 & mRNA-transfected DCs + IL-2 & $|/| \mid$ & Completed \\
\hline & NCT01530698 & autologous dendritic cell vaccine by mRNA Electroporation & $|/| \mid$ & Completed \\
\hline & NCT00243529 & Autologous dendritic cell vaccine & $|/| \mid$ & Completed \\
\hline & NCT03897881 & mRNA-4157 + pembrolizumab & $\|$ & Recruiting \\
\hline & NCT01456104 & $\begin{array}{l}\text { Autologous Langerhans-type dendritic cells electroporated with mRNA encoding a } \\
\text { tumor-associated antigen }\end{array}$ & I & $\begin{array}{l}\text { Active, not } \\
\text { recruiting }\end{array}$ \\
\hline & NCT02410733 & Lipo-MERIT & । & $\begin{array}{l}\text { Active, not } \\
\text { recruiting }\end{array}$ \\
\hline & NCT00961844 & $\begin{array}{l}\text { Dendritic cells - transfected with hTERT-, survivin- and tumor cell derived } \\
\text { mRNA+ex vivo T cell expansion and reinfusion+Temozolomide }\end{array}$ & $|/| \mid$ & Terminated \\
\hline & NCT03480152 & (NCl)-4650, a mRNA-based, personalized cancer vaccine & । & Terminated \\
\hline & NCT00929019 & Autologous dendritic cells electroporated with mRNA & $|/| \mid$ & Terminated \\
\hline \multirow{13}{*}{$\begin{array}{l}\text { Brain Cance (mainly } \\
\text { glioblastoma) }\end{array}$} & NCT00846456 & Tumor stem cell derived mRNA- transfected dendritic cells & $|/| \mid$ & Completed \\
\hline & NCT00626483 & CMV pp65-LAMP mRNA-loaded DC + GM-CSF & I & Completed \\
\hline & NCT03548571 & DCs transfected with mRNA encoding survivin and hTERT+temozolomide & $\|/\| 1 \|$ & Completed \\
\hline & NCT03927222 & $\begin{array}{l}\text { Human CMV pp65-LAMP mRNA-pulsed autologous DCs + temozolomide+tetanus- } \\
\text { diphtheria toxoid+GM-CSF }\end{array}$ & $\|$ & Recruiting \\
\hline & NCT02649582 & Autologous WT1 mRNA-loaded DC + temozolomide & $|/| \mid$ & Recruiting \\
\hline & NCT03688178 & $\begin{array}{l}\text { Human CMV pp65-LAMP mRNA-pulsed autologous DCs + temozolomide+varlilumab+- } \\
\text { tetanus-diphtheria (Td) toxoid+111 In-labeled DCs + unpulsed DCs }\end{array}$ & $\|$ & Recruiting \\
\hline & NCT02465268 & pp65-shLAMP mRNA DCs + GM-CSF & $\|$ & Recruiting \\
\hline & NCT02808416 & Personalized cellular vaccine & I & $\begin{array}{l}\text { Active, not } \\
\text { recruiting }\end{array}$ \\
\hline & NCT02709616 & mRNA-TAA pulsed autologous DC & I & $\begin{array}{l}\text { Active, not } \\
\text { recruiting }\end{array}$ \\
\hline & NCT00639639 & CMV-ALT+CMV pp65-LAMP mRNA-loaded DC (CMV-DC) & I & $\begin{array}{l}\text { Active, not } \\
\text { recruiting }\end{array}$ \\
\hline & NCT02366728 & Human CMV pp65-LAMP mRNA-pulsed autologous DCs & $\|$ & $\begin{array}{l}\text { Active, not } \\
\text { recruiting }\end{array}$ \\
\hline & NCT01291420 & WT1 mRNA-electroporated autologous dendritic cell & $|/| \mid$ & Unknown \\
\hline & NCT00890032 & BTSC mRNA-loaded DCs & I & Unknown \\
\hline \multirow[t]{2}{*}{ Prostate Cancer } & NCT01278914 & mRNA-transfected dendritic cells & $|/| \mid$ & Completed \\
\hline & NCT01446731 & DCs transfected with PSA, PAP, survivin and hTERT mRNA+docetaxel & $\|$ & Completed \\
\hline
\end{tabular}


Table 1 Clinical trials with mRNA vaccines against cancer (Continued)

\begin{tabular}{|c|c|c|c|c|}
\hline Cancer tpye & NCT number & Drug administration & Phase & Status \\
\hline & NCT02692976 & $\begin{array}{l}\text { DC loaded with protamine/mRNA encoding keyhole limpet hemocyanin }(\mathrm{KLH})+\mathrm{DC} \\
\text { loading with MHC I binding peptides, NY-ESO-1 and MUC1 PepTivator }{ }^{\circledast}\end{array}$ & $\|$ & Completed \\
\hline & NCT01197625 & Dendritic cell vaccine & $|/| \mid$ & $\begin{array}{l}\text { Active, not } \\
\text { recruiting }\end{array}$ \\
\hline & NCT01153113 & $\begin{array}{l}\text { Human telomerase reverse transcriptase mRNA (hTERT mRNA) transfected dendritic } \\
\text { cell }\end{array}$ & $|/| \mid$ & Withdrawn \\
\hline & NCT02140138 & CV9104 & $\|$ & Terminated \\
\hline & NCT02452307 & Peptide vaccine+montanide ISA-51+/-GM-CSF+/-imiquimod+/-mRNA/protamin & $|/| \mid$ & Unknown \\
\hline \multirow{9}{*}{$\begin{array}{l}\text { Blood System Cancer } \\
\text { (leukemia mainly) }\end{array}$} & NCT00834002 & Wilms Tumor Gene (WT1) mRNA-transfected autologous dendritic cell & I & Completed \\
\hline & NCT01734304 & DCs electroporated with mRNA encoding WT1, PRAME, and CMVpp65 & $|/| \mid$ & Completed \\
\hline & NCT00510133 & $\begin{array}{l}\text { GRNVAC1 (mRNA encoding human telomerase reverse transcriptase (hTERT) and a } \\
\text { portion of the lysosome-associated membrane protein LAMP-1 (LAMP)) }\end{array}$ & $\|$ & Completed \\
\hline & NCT02528682 & MiHA mRNA-loaded PD-L-silenced DC & $|/| \mid$ & Completed \\
\hline & NCT01686334 & Autologous WT1 mRNA-electroporated DCs & $\|$ & Recruiting \\
\hline & NCT01995708 & CT7, MAGE-A3, and WT1 mRNA-electroporated Langerhans cells (LCs) & I & $\begin{array}{l}\text { Active, not } \\
\text { recruiting }\end{array}$ \\
\hline & NCT03083054 & Autologous dendritic cells electroporated with WT1 mRNA & $|/| \mid$ & $\begin{array}{l}\text { Active, not } \\
\text { recruiting }\end{array}$ \\
\hline & NCT00514189 & Autologous dendritic cells & I & Terminated \\
\hline & NCT00965224 & mRNA coding for Wilms' tumor antigen WT1 & $\|$ & Unknown \\
\hline \multirow{3}{*}{$\begin{array}{l}\text { Digestive System } \\
\text { Cancer }\end{array}$} & NCT00228189 & CEA mRNA-loaded DCs & $|/| \mid$ & Completed \\
\hline & NCT03468244 & Personalized mRNA vaccine encoding neoantigen & - & Recruiting \\
\hline & NCT02693236 & Adenovirus-transfected autologous DCs + CIK cells & $|/| \mid$ & Unknown \\
\hline
\end{tabular}

leukemia. As for viral diseases, the majority of clinical trials is about SARS-CoV-2 and HIV-1.

\section{Discussion and conclusion}

In the past few decades, we witnessed the efficiency of mRNA vaccines in different delivery strategies, due to the safety, efficacy and industrial production of mRNA vaccines. In 2020, mRNA vaccines exerted a public concern for COVID-19. The majority of studies aimed at treating cancer, such as melanoma. The rest of the studies focus on viral diseases, including COVID-19, rabies, respiratory syncytial virus infection, zika virus infection, cytomegalovirus infection, human metapneumovirus and human parainfluenza infection, HIV infection, Ebola virus infection and influenza.

Investigations of mRNA vaccines should not leave eliminating mRNA immunogenicity, stabilizing mRNA vaccines, increasing the antigen reactiveness, producing effective imminity, adding immunological adjuvants and developing effective delivery system. After sequence optimization, mRNAs are stable and less immunogenitic. Based on the immunology, mRNAs are first sensed by innate immunity, followed by PRRs/PAMPs-mediated cascades of the signaling pathway. Activated innate immunity triggers adaptive immunity. More extensive researches focus on different delivery strategies. LNPs, polymers and peptides have enabled the mRNAdelivering efficacy more robust and the exploration indepth. Induced cellular responses and neutralizing antibodies are witnessed in mice, nonhuman primates and human beings. VRP and CNE also potentiate the delivering efficacy and broaden the scope of delivery strategies. Some immunologic adjuvants are also supplemented to enhance immunogenicity, increase titers of antibodies, alter types of antibody production and strengthen delayed hypersensitivities. Alternatively, the naked mRNA showed the priority under the condition of appropriate administration methods and chemical modifications. Furthermore, the classical APCs (DCs) can deliver antigen-encoding mRNAs by encapsulation, eliciting antigen-specific immune responses.

Most of the mRNA vaccine studies are tumoral and viral. Except for tumoral and viral targets, scientists also applied mRNA vaccines to bacterial infection and parasitic diseases. For example, Maruggi et al. used saRNA encoding antigens from Group A and Group B Streptococci to immunize mice with Group A Streptococci infection and Group B Streptococci infection separately. The mRNA vaccine had sustained protection in mice by producing functional serum antibodies [224]. Another study evaluated saRNA efficacy in malaria. saRNA encoding plasmodium macrophage migration inhibitory 
Table 2 Clinical trials with mRNA vaccines against viral diseases

\begin{tabular}{|c|c|c|c|c|}
\hline Infectious disease tpye/ Virus type & NCT number & Drug administration & Phase & Status \\
\hline \multirow[t]{7}{*}{ SARS-CoV-2 } & NCT04523571 & BNT162b1 + placebo & I & Recruiting \\
\hline & NCT04449276 & CVnCoV Vaccine+placebo & I & Recruiting \\
\hline & NCT04470427 & mRNA-1273 + placebo & III & Recruiting \\
\hline & NCT04368728 & BNT162b1 + BNT162b2 & $|/||/|||$ & Recruiting \\
\hline & NCT04515147 & CVnCoV & $\| A$ & $\begin{array}{l}\text { Not yet } \\
\text { recruiting }\end{array}$ \\
\hline & NCT04283461 & mRNA-1273 & I & $\begin{array}{l}\text { Active, not } \\
\text { recruiting }\end{array}$ \\
\hline & NCT04405076 & mRNA-1273 + placebo & $\| A$ & $\begin{array}{l}\text { Active, not } \\
\text { recruiting }\end{array}$ \\
\hline \multirow[t]{2}{*}{ Rabies } & NCT02241135 & CV7201 mRNA encoding the rabies virus glycoprotein & I & Completed \\
\hline & NCT03713086 & Rabipur ${ }^{\oplus}$ & I & $\begin{array}{l}\text { Active, not } \\
\text { recruiting }\end{array}$ \\
\hline \multirow[t]{3}{*}{ HIV-1 Infection } & NCT00833781 & $\begin{array}{l}\text { mRNA-transfected autologous DCs+/- autologous DCs with } \\
\text { no mRNA transfection }\end{array}$ & $|/| \mid$ & Completed \\
\hline & NCT02413645 & TriMix mRNA+/-HIV mRNA & I & Completed \\
\hline & NCT02888756 & iHIVARNA-01 + TriMix+/-Placebo & $\| \mathrm{A}$ & Terminated \\
\hline \multirow[t]{2}{*}{ Zika Virus } & NCT03014089 & mRNA-1325 + placebo & I & Completed \\
\hline & NCT04064905 & mRNA-1893 + placebo & I & $\begin{array}{l}\text { Active, not } \\
\text { recruiting }\end{array}$ \\
\hline Tuberculosis & NCT01669096 & GSK 692342 & $\|$ & Completed \\
\hline \multirow{2}{*}{$\begin{array}{l}\text { Human Metapneumovirus and Human } \\
\text { Parainfluenza Infection }\end{array}$} & NCT03392389 & mRNA-1653 + placebo & 1 & Completed \\
\hline & NCT04144348 & mRNA-1653 + placebo & $\mathrm{lb}$ & Recruiting \\
\hline Ebola Virus Disease & NCT02485912 & $\begin{array}{l}\text { two separate mRNAs encoding two Zaire strain Ebola } \\
\text { glycoproteins, respectively }\end{array}$ & I & Completed \\
\hline Influenza & NCT03076385 & VAL-506440 + placebo & I & Completed \\
\hline Respiratory Syncytial Virus & NCT04528719 & mRNA-1345 + placebo & I & $\begin{array}{l}\text { Not yet } \\
\text { recruiting }\end{array}$ \\
\hline \multirow[t]{2}{*}{ Cytomegalovirus Infection } & NCT03382405 & mRNA-1647, mRNA-1443 & I & $\begin{array}{l}\text { Active, not } \\
\text { recruiting }\end{array}$ \\
\hline & NCT04232280 & mRNA-1647 + placebo & $\|$ & $\begin{array}{l}\text { Active, not } \\
\text { recruiting }\end{array}$ \\
\hline
\end{tabular}

factor (PMIF) elicited cellular/humoral immune responses and PMIF-specific immunoglobulin G. The saRNA vaccine delayed blood-stage latency after sporozoite infection and increased the number of liverresident $\mathrm{CD} 8+\mathrm{T}$ cells and antigen-experienced memory CD4 + T cells. Surprisingly, the vaccine protected mice from re-infection by adoptively transferring $\mathrm{CD}^{+}$and $\mathrm{CD}^{+} \mathrm{T}$ cells [225].

Even so, researches of mRNA vaccines against bacteria and parasites are limited. No vaccine relating to bacteria and parasites has been approved so far. As for bacteria, they are one hundred times larger than viruses. Hence, there are differences in the structural complexity and immunology between them. The virus composition constitutes only dozens of antigens. However, bacterial composition can constitue thousands of antigens bacause bacteria have cell walls, cell membranes, fimbriae, capsules, proteins and nucleic acids. It is extremely difficult to find antigens that can be made into vaccines in bacteria. A second reason is that common bacterial diseases are not violent infectious diseases. Most diseases have been treated with effective antibiotics. The cost of antibiotic production is low. So mRNA vaccines are less important in bacterial diseases. As for parasites, it is difficult to obtain live attenuated vaccines in vitro because of their parasitism. Compared with bacteria, it is much more difficult to obtain effective and multivalent vaccines because parasites' reproduction cycle and antigen composition are more complex. Moreover, some parasites induce severe hypersensitivity. Other parasites cause mechanical damage to host tissue and capture nutrition without causing immune responses. A proportion of parasites are able to escape immunity. More importantly, there have been effective antiparasitic drugs. 
Therefore, mRNA vaccines are less common in parasitic diseases.

In terms of the above difficulties, we should identify new candidate antigens and develop multiple multivalent vaccines. Most significantly, we should enhance vaccine's immunogenicity and titers of protective antibodies.

Although mRNA vaccines in tumors and viruses have multiple advantages, they are still in the initial stage. Currently, safety is the most significant issue. ADE should be considered in developing mRNA vaccines. Their intended use would be assessed by cost/benefit ratio. Expenses and efforts determine the ultimate demonstration of solving a medical problem. We hope that mRNA vaccines' future is bright. Clinical trials would turn basic reseach into mRNA therapeutics in medical practices.

\begin{abstract}
Abbreviations
HPV: Human papillomavirus; HSV-2: Herpes simplex virus 2; saRNA: Selfamplifying RNA; UTR: Untranslated regions; ORF: Open reading frame; HA: Hemagglutinin; CGMP: Current Good Manufacturing Practices; taRNA: Trans-amplifying RNA; LNA: Locked nucleic acid; TAAs: Tumorassociated antigens; TCR: T cell receptors; CTL: Cytotoxic-T-lymphocyte; OVA: Ovalbumin; BMDCs: Bone marrow-derived dendritic cells; SARS-CoV2: Severe acute respiratory syndrome coronavirus 2; PRRs: Pattern recognition receptors; TLR: Toll-like-receptor; dsRNA: Double-stranded RNA; ssRNA: Singlestranded RNA; NOS2: Nitric oxide synthase; RIG-I: Retinoic acid-inducible gene I; NOD: Nucleotide oligomerization domain; NLRs: NOD-like receptors; PKR: Protein kinase receptor; OAS: Oligoadenylate synthetase; CNE: Cationic nanoemulsion; LNPs: Lipid nanoparticles; ER: Reticuloendothelial; ApoE: Apolipoprotein E; LDLR: Low density lipoprotein receptor; DOTMA: N[1-(2,3-dioleoyloxy) propyl]-N,N,N-trimethylammonium chloride; Dlin-MC3DMA: Dilinoleylmethyl-4-dimethylaminobutyrate; DLinDMA: N,N-Dimethyl2,3-bis[(9Z,12Z)-octadeca-9,12-dienyloxy]propan-1-amine; DOPE: 1,2-dioleoylsn-glycerol-3-phosphoethanolamine; DOTAP: 1,2-dioleoyloxy-3trimethylammonium propane chloride; TT3: $\mathrm{N}^{1}, \mathrm{~N}^{3}, \mathrm{~N}^{5}$-tris(3(didodecylamino)propyl)benzene-1,3,5-tricarboxamide; STING: Stimulator of interferon genes; SC: Subcutaneous; IM: Intramuscular; ID: Intradermal; IN: Intranodal; APC: Antigen-presenting cells; LPRs: Lipid-polymer-RNA lipopolyplexes; IV: Intravenous; PEl: Polyethylenimine; PAMA M: Polyamidoamine; NALT: Nasal associated lymphoid tissue; CP 2 k: Cyclodextrin-polyethylenimine 2 k conjugate; PLGA: Poly(lactic-co-glycolic acid); NGA: Nanogel-alginate; CLAN: Lipid-assisted nanoparticles; CPP: Cationic cell-penetrating peptides; VRPs: Virus-like Replicon Particles; LIONs: Lipid inorganic nanoparticles; G-CSF: Granulocyte colony-stimulating factor; CNE: Cationic Nanoemulsion; RSV: Respiratory syncytial virus; hCMV: Human cytomegalovirus; HIV: Human immunodeficiency virus; FLT3: Fms-like tyrosine kinase 3; TiDC: Tumor-infiltrating dendritic cell; MHC: Major histocompatibility complex; TNFRSF4: Tumour necrosis factor receptor superfamily member 4; WT1: Tumor gene 1; COVID-19: Corona Virus Disease 2019; SARS-CoV-2: Severe Acute Respiratory Syndrome Coronavirus 2; RBD: Receptor-binding domain; GCs: Germinal centres; IVT: In vitro transcription; EPO: Erythropoietin; ADE: Antibody-dependent enhancement
\end{abstract}

\section{Acknowledgements}

We really appreciate Biao An, Yanghong $\mathrm{Ni}$ and Jia Yang to give us guidance about making figures.

\section{Authors' contributions}

Yuquan Wei and Xiawei Wei offered main direction and significant guidance of this manuscript. Yang Wang and Ziqi Zhang drafted the manuscript and illustrated the figures for the manuscript. Jingwen Luo and Xuejiao Han made figures and tables and revised the manuscript. Yang Wang, Ziqi Zhang, Jingwen Luo and Xuejiao Han contributed equally to the work. The author(s) read and approved the final manuscript.

\section{Funding}

This work is supported by the National Natural Science Foundation Regional Innovation and Development (U19A2003), National Major Scientific and Technological Special Project for "Significant New Drugs Development" (No. 2018ZX09733001), the Excellent Youth Foundation of Sichuan Scientific Committee Grant in China (No. 2019JDJQ008) and the Development Program of China (No. 2016YFA0201402).

Availability of data and materials

Not applicable.

Ethics approval and consent to participate

Not applicable.

\section{Consent for publication}

All authors consent to publication.

\section{Competing interests}

The authors declare that they have no competing interests.

Received: 22 October 2020 Accepted: 8 January 2021

Published online: 16 February 2021

\section{References}

1. Rabinovich NR, McInnes P, Klein DL, Hall BF. Vaccine technologies: view to the future. Science. 1994;265:1401-4.

2. Moore ZS, Seward JF, Lane JM. Smallpox. Lancet. 2006;367:425-35.

3. Malagón T, Drolet M, Boily MC, Franco EL, Jit M, Brisson J, Brisson M. Crossprotective efficacy of two human papillomavirus vaccines: a systematic review and meta-analysis. Lancet Infect Dis. 2012;12:781-9.

4. Kirby T. FDA approves new upgraded Gardasil 9. Lancet Oncol. 2015;16:e56.

5. Rodrigues CMC, Pinto MV, Sadarangani M, Plotkin SA. Whither vaccines? J Inf Secur. 2017;74(Suppl 1):S2-s9.

6. Pollard C, De Koker S, Saelens X, Vanham G, Grooten J. Challenges and advances towards the rational design of mRNA vaccines. Trends Mol Med. 2013;19:705-13.

7. Linares-Fernández S, Lacroix C, Exposito JY, Verrier B. Tailoring mRNA vaccine to balance innate/adaptive immune response. Trends Mol Med. 2020;26:311-23.

8. Wolff JA, Malone RW, Williams P, Chong W, Acsadi G, Jani A, Felgner PL. Direct gene transfer into mouse muscle in vivo. Science. 1990;247:1465-8.

9. Jirikowski GF, Sanna PP, Maciejewski-Lenoir D, Bloom FE. Reversal of diabetes insipidus in Brattleboro rats: intrahypothalamic injection of vasopressin mRNA. Science. 1992;255:996-8.

10. Pardi N, Hogan MJ, Weissman D. Recent advances in mRNA vaccine technology. Curr Opin Immunol. 2020;65:14-20.

11. Naik R, Peden K. Regulatory considerations on the development of mRNA vaccines. Curr Top Microbiol Immunol. 2020. Epub ahead of print.

12. Rice AM, Morales AC, Ho AT, Mordstein C, Mühlhausen S, Watson S, Cano L, Young B, Kudla G, Hurst LD. Evidence for strong mutation bias towards, and selection against, $U$ content in SARS-CoV-2: implications for vaccine design. Mol Biol Evol. 2020;38:67-83.

13. Brito LA, Kommareddy S, Maione D, Uematsu Y, Giovani C, Berlanda Scorza F, Otten GR, Yu D, Mandl CW, Mason PW, et al. Self-amplifying mRNA vaccines. Adv Genet. 2015;89:179-233.

14. Alberer M, Gnad-Vogt U, Hong HS, Mehr KT, Backert L, Finak G, Gottardo R, Bica MA, Garofano A, Koch SD, et al. Safety and immunogenicity of a mRNA rabies vaccine in healthy adults: an open-label, non-randomised, prospective, first-in-human phase 1 clinical trial. Lancet. 2017;390:1511-20.

15. Kirschman JL, Bhosle S, Vanover D, Blanchard EL, Loomis KH, Zurla C, Murray K, Lam BC, Santangelo PJ. Characterizing exogenous mRNA delivery, trafficking, cytoplasmic release and RNA-protein correlations at the level of single cells. Nucleic Acids Res. 2017;45:e113.

16. Wroblewska L, Kitada T. Mammalian synthetic circuits with RNA binding proteins for RNA-only delivery. Nat Biotechnol. 2015;33:839-41.

17. He S, Fan W, Wu N, Zhu J, Miao Y, Miao X, Li F, Zhang X, Gan Y. Lipid-based liquid crystalline nanoparticles facilitate cytosolic delivery of siRNA via structural transformation. Nano Lett. 2018;18:2411-9.

18. Kaczmarek JC, Kowalski PS, Anderson DG. Advances in the delivery of RNA therapeutics: from concept to clinical reality. Genome Med. 2017;9:60. 
19. Zhu G, Zhang F. Efficient nanovaccine delivery in cancer immunotherapy. ACS Nano. 2017;11:2387-92.

20. Blakney AK, Zhu Y. Big is beautiful: enhanced saRNA delivery and immunogenicity by a higher molecular weight, bioreducible, cationic polymer. ACS Nano. 2020;14:5711-27.

21. Egan KP, Hook LM. An HSV-2 nucleoside-modified mRNA genital herpes vaccine containing glycoproteins $\mathrm{gC}, \mathrm{gD}$, and gE protects mice against HSV1 genital lesions and latent infection. PLoS Pathog. 2020;16:e1008795.

22. Wang F, Xiao W, Elbahnasawy MA, Bao X, Zheng Q, Gong L, Zhou Y, Yang S, Fang A, Farag MMS, et al. Optimization of the linker length of mannosecholesterol conjugates for enhanced mRNA delivery to dendritic cells by liposomes. Front Pharmacol. 2018;9:980.

23. Pardi N, Hogan MJ, Pelc RS, Muramatsu H, Andersen H, DeMaso CR, Dowd KA, Sutherland LL, Scearce RM, Parks R, et al. Zika virus protection by a single low-dose nucleoside-modified mRNA vaccination. Nature. 2017;543: 248-51.

24. Corbett KS, Edwards DK, Leist SR, Abiona OM, Boyoglu-Barnum S, Gillespie RA, Himansu S, Schäfer A, Ziwawo CT, DiPiazza AT, Dinnon KH. SARS-CoV-2 mRNA vaccine design enabled by prototype pathogen preparedness. Nature. 2020;586:567-71.

25. Corbett KS, Flynn B, Foulds KE, Francica JR, Boyoglu-Barnum S, Werner AP, Flach B, O'Connell S, Bock KW, Minai M, et al. Evaluation of the mRNA-1273 vaccine against SARS-CoV-2 in nonhuman primates. N Engl J Med. 2020;383: 1544-55.

26. Tai W, Zhang X, Drelich A, Shi J, Hsu JC, Luchsinger L, Hillyer CD, Tseng CK, Jiang S, Du L. A novel receptor-binding domain (RBD)-based mRNA vaccine against SARS-CoV-2. Cell Res. 2020;30:932-5.

27. Shin MD, Shukla S, Chung YH. COVID-19 vaccine development and a potential nanomaterial path forward. Nat Nanotechnol. 2020;15:646-55.

28. Jackson NAC, Kester KE. The promise of mRNA vaccines: a biotech and industrial perspective. NPJ Vaccines. 2020;5:11.

29. Sullenger BA, Nair S. From the RNA world to the clinic. Science. 2016;352: 1417-20.

30. Liang F, Lindgren G, Lin A, Thompson EA, Ols S, Röhss J, John S, Hassett K, Yuzhakov O, Bahl K, et al. Efficient targeting and activation of antigenpresenting cells in vivo after modified mRNA vaccine aministration in rhesus macaques. Mol Ther. 2017;25:2635-47.

31. Pickering BM, Willis AE. The implications of structured 5 ' untranslated regions on translation and disease. Semin Cell Dev Biol. 2005;16:39-47.

32. Chatterjee S, Pal JK. Role of 5'- and 3'-untranslated regions of mRNAs in human diseases. Biol Cell. 2009;101:251-62.

33. Furuichi $Y$, LaFiandra A, Shatkin AJ. 5'-terminal structure and mRNA stability. Nature. 1977;266:235-9.

34. Brenner S, Jacob F, Meselson M. An unstable intermediate carrying information from genes to ribosomes for protein synthesis. Nature. 1961; 190:576-81.

35. Lundstrom K. Self-amplifying RNA viruses as RNA vaccines. Int J Mol Sci. 2020:21:5130.

36. Deering RP, Kommareddy S, UImer JB, Brito LA, Geall AJ. Nucleic acid vaccines: prospects for non-viral delivery of mRNA vaccines. Expert Opin Drug Deliv. 2014;11:885-99.

37. Berglund P, Smerdou C, Fleeton MN, Tubulekas I, Liljeström P. Enhancing immune responses using suicidal DNA vaccines. Nat Biotechnol. 1998;16: 562-5.

38. Biddlecome A, Habte HH, McGrath KM, Sambanthamoorthy S, Wurm M, Sykora MM, Knobler CM, Lorenz IC. Delivery of self-amplifying RNA vaccines in in vitro reconstituted virus-like particles. PLoS One. 2019;14:e0215031.

39. Englezou PC, Sapet C, Démoulins T, Milona P, Ebensen T, Schulze K, Guzman CA, Poulhes F, Zelphati O, Ruggli N, McCullough KC. Selfamplifying replicon RNA delivery to dendritic cells by cationic lipids. Mol Ther Nucleic Acids. 2018;12:118-34.

40. Beissert T, Perkovic M, Vogel A, Erbar S, Walzer KC, Hempel T, Brill S, Haefner E, Becker R, Türeci Ö, Sahin U. A trans-amplifying RNA vaccine strategy for induction of potent protective immunity. Mol Ther. 2020;28:119-28.

41. Sahin U, Karikó K, Türeci Ö. mRNA-based therapeutics--developing a new class of drugs. Nat Rev Drug Discov. 2014;13:759-80.

42. Pozzi B, Bragado L, Mammi P, Torti MF, Gaioli N, Gebhard LG, García Solá ME, Vaz-Drago R, Iglesias NG, García CC, et al. Dengue virus targets RBM10 deregulating host cell splicing and innate immune response. Nucleic Acids Res. 2020:48:6824-38.
43. Hornung $V$, Barchet $W$, Schlee $M$, Hartmann G. RNA recognition via TLR7 and TLR8. Handb Exp Pharmacol. 2008:(183):71-86.

44. Thess A, Grund S, Mui BL, Hope MJ, Baumhof P, Fotin-Mleczek M, Schlake T. Sequence-engineered mRNA without chemical nucleoside modifications enables an effective protein therapy in large animals. Mol Ther. 2015;23: 1456-64.

45. Weng Y, Li C, Yang T, Hu B, Zhang M, Guo S, Xiao H, Liang XJ, Huang Y. The challenge and prospect of mRNA therapeutics landscape. Biotechnol Adv. 2020;40:107534

46. Weissman D, Karikó K. mRNA: fulfilling the promise of gene therapy. Mol Ther. 2015;23:1416-7.

47. Batey RT, Kieft JS. Improved native affinity purification of RNA. RNA. 2007;13: 1384-9.

48. Weissman D, Pardi N, Muramatsu H, Karikó K. HPLC purification of in vitro transcribed long RNA. Methods Mol Biol. 2013;969:43-54.

49. Pardi N, Secreto AJ, Shan X, Debonera F, Glover J, Yi Y, Muramatsu H, Ni H, Mui BL, Tam YK, et al. Administration of nucleoside-modified mRNA encoding broadly neutralizing antibody protects humanized mice from HIV1 challenge. Nat Commun. 2017;8:14630.

50. Conry RM, LoBuglio AF, Wright M, Sumerel L, Pike MJ, Johanning F, Benjamin R, Lu D, Curiel DT. Characterization of a messenger RNA polynucleotide vaccine vector. Cancer Res. 1995;55:1397-400.

51. Kore AR, Shanmugasundaram M, Charles I, Vlassov AV, Barta TJ. Locked nucleic acid (LNA)-modified dinucleotide mRNA cap analogue: synthesis, enzymatic incorporation, and utilization. J Am Chem Soc. 2009;131:6364-5.

52. Jani B, Fuchs R. In vitro transcription and capping of Gaussia luciferase mRNA followed by HeLa cell transfection. J Vis Exp. 2012;(61):3702.

53. Stepinski J, Waddell C, Stolarski R, Darzynkiewicz E, Rhoads RE. Synthesis and properties of mRNAs containing the novel "anti-reverse" cap analogs 7-methyl(3'O-methyl)GpppG and 7-methyl (3'-deoxy)GpppG. RNA. 2001;7:1486-95.

54. Urbina F, Morales-Pison S. Enzymatic protein biopolymers as a tool to synthetize eukaryotic messenger ribonucleic acid (mRNA) with uses in vaccination, immunotherapy and nanotechnology. Polymers (Basel). 2020;12: 1633.

55. Whitelaw E, Coates A, Proudfoot NJ. Globin gene transcripts can utilize histone gene 3' end processing signals. Nucleic Acids Res. 1986;14:7059-70.

56. Doel MT, Carey NH. The translational capacity of deadenylated ovalbumin messenger RNA. Cell. 1976;8:51-8.

57. Holtkamp S, Kreiter S, Selmi A, Simon P, Koslowski M, Huber C, Türeci O, Sahin U. Modification of antigen-encoding RNA increases stability, translational efficacy, and T-cell stimulatory capacity of dendritic cells. Blood. 2006;108:4009-17.

58. Shabalina SA, Spiridonov NA, Kashina A. Sounds of silence: synonymous nucleotides as a key to biological regulation and complexity. Nucleic Acids Res. 2013;41:2073-94.

59. Kudla G, Lipinski L, Caffin F, Helwak A, Zylicz M. High guanine and cytosine content increases mRNA levels in mammalian cells. PLoS Biol. 2006:4:e180.

60. Homma K, Noguchi T, Fukuchi S. Codon usage is less optimized in eukaryotic gene segments encoding intrinsically disordered regions than in those encoding structural domains. Nucleic Acids Res. 2016;44:10051-61.

61. Zhong C, Wei P, Zhang YP. Enhancing functional expression of codonoptimized heterologous enzymes in Escherichia coli BL21(DE3) by selective introduction of synonymous rare codons. Biotechnol Bioeng. 2017;114: 1054-64.

62. Yokokawa H, Higashino A, Suzuki S, Moriyama M, Nakamura N, Suzuki T, Suzuki R, Ishii K, Kobiyama K, Ishii KJ, et al. Induction of humoural and cellular immunity by immunisation with HCV particle vaccine in a nonhuman primate model. Gut. 2018;67:372-9.

63. Monslow MA, Elbashir S, Sullivan NL, Thiriot DS, Ahl P, Smith J, Miller E, Cook J, Cosmi S, Thoryk E, et al. Immunogenicity generated by mRNA vaccine encoding VZV gE antigen is comparable to adjuvanted subunit vaccine and better than live attenuated vaccine in nonhuman primates. Vaccine. 2020;38:5793-802.

64. Tateshita N, Miura N, Tanaka H, Masuda T, Ohtsuki S, Tange K, Nakai Y, Yoshioka H, Akita H. Development of a lipoplex-type mRNA carrier composed of an ionizable lipid with a vitamin E scaffold and the KALA peptide for use as an ex vivo dendritic cell-based cancer vaccine. J Control Release. 2019;310:36-46.

65. Joe PT, Christopoulou I, van Hoecke L, Schepens B, Ysenbaert T, Heirman C, Thielemans K, Saelens X, Aerts JL. Intranodal administration of mRNA 
encoding nucleoprotein provides cross-strain immunity against influenza in mice. J Transl Med. 2019;17:242.

66. Yang Y, Li CW, Chan LC, Wei Y, Hsu JM, Xia W, Cha JH, Hou J, Hsu JL, Sun L, Hung MC. Exosomal PD-L1 harbors active defense function to suppress $T$ cell killing of breast cancer cells and promote tumor growth. Cell Res. 2018; 28:862-4.

67. Cano F, Lehner PJ. A novel post-transcriptional role for ubiquitin in the differential regulation of MHC class I allotypes. Mol Immunol. 2013;55:135-8.

68. Yamamoto K, Venida A, Yano J, Biancur DE, Kakiuchi M, Gupta S, Sohn ASW, Mukhopadhyay S, Lin EY, Parker SJ, et al. Autophagy promotes immune evasion of pancreatic cancer by degrading MHC-I. Nature. 2020;581:100-5.

69. Campillo-Davo D, Versteven M, Roex G, Reu H, Heijden SV, Anguille S, Berneman ZN, Tendeloo V, Lion E. Rapid assessment of functional avidity of tumor-specific $T$ cell receptors using an antigen-presenting tumor cell line electroporated with full-length tumor antigen mRNA. Cancers (Basel). 2020; 12(2):256.

70. Hess PR, Boczkowski D, Nair SK, Snyder D, Gilboa E. Vaccination with mRNAs encoding tumor-associated antigens and granulocyte-macrophage colonystimulating factor efficiently primes CTL responses, but is insufficient to overcome tolerance to a model tumor/self antigen. Cancer Immunol Immunother. 2006;55:672-83.

71. Lindgren $\mathrm{G}$, Ols S, Liang F, Thompson EA, Lin A, Hellgren F, Bahl K, John S, Yuzhakov $\mathrm{O}$, Hassett $\mathrm{K}$, et al. Induction of robust $\mathrm{B}$ cell responses after influenza mRNA vaccination is accompanied by circulating hemagglutinin-specific ICOS+ PD-1+ CXCR3+ T follicular helper cells. Front Immunol. 2017;8:1539.

72. Basso K, Dalla-Favera R. Germinal centres and B cell lymphomagenesis. Nat Rev Immunol. 2015;15:172-84.

73. Heyman B. Regulation of antibody responses via antibodies, complement, and Fc receptors. Annu Rev Immunol. 2000;18:709-37.

74. Tam HH, Melo MB. Sustained antigen availability during germinal center initiation enhances antibody responses to vaccination. Proc Natl Acad Sci U S A. 2016;113:E6639-e6648.

75. Bahl K, Senn JJ, Yuzhakov O, Bulychev A, Brito LA, Hassett KJ, Laska ME, Smith M, Almarsson Ö, Thompson J, et al. Preclinical and clinical demonstration of immunogenicity by mRNA vaccines against H10N8 and H7N9 influenza viruses. Mol Ther. 2017:25:1316-27.

76. Fleeton MN, Chen M, Berglund P, Rhodes G, Parker SE, Murphy M, Atkins GJ, Liljeström P. Self-replicative RNA vaccines elicit protection against influenza a virus, respiratory syncytial virus, and a tickborne encephalitis virus. J Infect Dis. 2001;183:1395-8.

77. McCullough KC, Bassi I, Milona P, Suter R, Thomann-Harwood L, Englezou P, Démoulins T, Ruggli N. Self-replicating replicon-RNA delivery to dendritic cells by chitosan-nanoparticles for translation in vitro and in vivo. Mol Ther Nucleic Acids. 2014;3:e173.

78. Démoulins T, Milona P, Englezou PC, Ebensen T, Schulze K, Suter R, Pichon C, Midoux P, Guzmán CA, Ruggli N, McCullough KC. Polyethylenimine-based polyplex delivery of self-replicating RNA vaccines. Nanomedicine. 2016;12: 711-22.

79. Liehl P, Zuzarte-Luís V, Chan J, Zillinger T, Baptista F, Carapau D, Konert M, Hanson KK, Carret C, Lassnig C, et al. Host-cell sensors for plasmodium activate innate immunity against liver-stage infection. Nat Med. 2014;20:47-53.

80. Blanco-Melo D, Nilsson-Payant BE, Liu WC, Uhl S, Hoagland D, Møller R, Jordan TX, Oishi K, Panis M, Sachs D, et al. Imbalanced host response to SARS-CoV-2 drives development of COVID-19. Cell. 2020;181:1036-1045. e1039.

81. Jain A, Irizarry-Caro RA. T cells instruct myeloid cells to produce inflammasome-independent IL-1 $\beta$ and cause autoimmunity. Nat Immunol. 2020:21:65-74.

82. Chow KT, Gale M Jr, Loo YM. RIG-I and other RNA sensors in antiviral immunity. Annu Rev Immunol. 2018;36:667-94.

83. Medzhitov R, Preston-Hurlburt P, Janeway CA Jr. A human homologue of the Drosophila toll protein signals activation of adaptive immunity. Nature. 1997;388:394-7.

84. Bergougnan C, Dittlein DC, Hümmer E, Riepl R, Eisenbart S, Böck D, Griesbaum L, Weigl A, Damialis A, Hartwig A, et al. Physical and immunological barrier of human primary nasal epithelial cells from nonallergic and allergic donors. World Allergy Organ J. 2020;13:100109.

85. Veetil AT, Zou J, Henderson KW. DNA-based fluorescent probes of NOS2 activity in live brains. Proc Natl Acad Sci U S A. 2020;117:14694-702.
86. Feng H, Lenarcic EM, Yamane D, Wauthier E, Mo J, Guo H, McGivern DR NLRX1 promotes immediate IRF1-directed antiviral responses by limiting dsRNA-activated translational inhibition mediated by PKR. Nat Immunol. 2017:18:1299-309.

87. Ilan L, Osman F, Namer LS, Eliahu E, Cohen-Chalamish S, Ben-Asouli Y, Banai Y, Kaempfer R. PKR activation and elF2a phosphorylation mediate human globin mRNA splicing at spliceosome assembly. Cell Res. 2017;27:688-704.

88. Ghosh A, Shao L, Sampath P, Zhao B, Patel NV, Zhu J, Behl B, Parise RA, Beumer JH, O'Sullivan RJ, et al. Oligoadenylate-synthetase-family protein OASL inhibits activity of the DNA sensor CGAS during DNA virus infection to limit interferon production. Immunity. 2019;50:51-63.e55.

89. Lin H, Jiang M, Liu L, Yang Z, Ma Z, Liu S. The long noncoding RNA Lnczc3h7a promotes a TRIM25-mediated RIG-I antiviral innate immune response. Nat Immunol. 2019;20:812-23.

90. Kaempfer R. Interferon-gamma mRNA attenuates its own translation by activating PKR: a molecular basis for the therapeutic effect of interferonbeta in multiple sclerosis. Cell Res. 2006;16:148-53.

91. Bogers WM, Oostermeijer H, Mooij P, Koopman G, Verschoor EJ, Davis D, Ulmer JB, Brito LA, Cu Y, Banerjee $K$, et al. Potent immune responses in rhesus macaques induced by nonviral delivery of a self-amplifying RNA vaccine expressing HIV type 1 envelope with a cationic nanoemulsion. J Infect Dis. 2015;211:947-55.

92. Brito LA, Chan M, Shaw CA, Hekele A, Carsillo T, Schaefer M, Archer J, Seubert A, Otten GR, Beard CW, et al. A cationic nanoemulsion for the delivery of next-generation RNA vaccines. Mol Ther. 2014;22:2118-29.

93. De Keersmaecker B, Claerhout S, Carrasco J, Bar I, Corthals J, Wilgenhof S, Neyns B, Thielemans K. TriMix and tumor antigen mRNA electroporated dendritic cell vaccination plus ipilimumab: link between T-cell activation and clinical responses in advanced melanoma. J Immunother Cancer. 2020; 8(1):e000329.

94. Bialkowski $L$, van Weijnen $A$, Van der Jeught $K$, Renmans $D$, Daszkiewicz $L$, Heirman C, Stangé G, Breckpot K, Aerts JL, Thielemans K. Intralymphatic mRNA vaccine induces CD8 T-cell responses that inhibit the growth of mucosally located tumours. Sci Rep. 2016;6:22509.

95. Leal L, Guardo AC, Morón-López S, Salgado M, Mothe B, Heirman C, Pannus P. Vanham G, van den Ham HJ, Gruters R, et al. Phase I clinical trial of an intranodally administered mRNA-based therapeutic vaccine against HIV-1 infection. AIDS. 2018;32:2533-45.

96. de Jong W, Aerts J, Allard S, Brander C, Buyze J, Florence E, van Gorp E, Vanham G, Leal L, Mothe B, et al. iHIVARNA phase lla, a randomized, placebo-controlled, double-blinded trial to evaluate the safety and immunogenicity of iHIVARNA-01 in chronically HIV-infected patients under stable combined antiretroviral therapy. Trials. 2019;20:361.

97. Jong W, Leal L, Buyze J, Pannus P, Guardo A, Salgado M, Mothe B, Molto J, Moron-Lopez S, Gálvez C, et al. Therapeutic vaccine in chronically HIV-1infected patients: a randomized, double-blind, placebo-controlled phase lla trial with HTI-TriMix. Vaccines (Basel). 2019;7(4):209.

98. Kübler H, Scheel B, Gnad-Vogt U, Miller K, Schultze-Seemann W, Vom Dorp F, Parmiani G, Hampel C, Wedel S, Trojan L, et al. Self-adjuvanted mRNA vaccination in advanced prostate cancer patients: a first-in-man phase I/lla study. J Immunother Cancer. 2015;3:26.

99. Fotin-Mleczek M, Zanzinger K, Heidenreich R, Lorenz C, Thess A, Duchardt KM, Kallen KJ. Highly potent mRNA based cancer vaccines represent an attractive platform for combination therapies supporting an improved therapeutic effect. J Gene Med. 2012;14:428-39.

100. Weide B, Carralot JP, Reese A, Scheel B, Eigentler TK, Hoerr I, Rammensee HG, Garbe C, Pascolo S. Results of the first phase I/II clinical vaccination trial with direct injection of mRNA. J Immunother. 2008;31:180-8.

101. Sebastian M, Papachristofilou A, Weiss C, Früh M, Cathomas R, Hilbe W, Wehler T, Rippin G, Koch SD, Scheel B, et al. Phase lb study evaluating a self-adjuvanted mRNA cancer vaccine (RNActive ${ }^{\oplus}$ ) combined with local radiation as consolidation and maintenance treatment for patients with stage IV non-small cell lung cancer. BMC Cancer. 2014;14:748.

102. Ziegler A, Soldner C, Lienenklaus S, Spanier J. A new RNA-based adjuvant enhances virus-specific vaccine responses by locally triggering TLR- and RLH-dependent effects. J Immunol. 2017;198:1595-605.

103. Mauriello A, Manolio C, Cavalluzzo B, Avallone A, Borrelli M, Morabito A, lovine E, Chambery A, Russo R, Tornesello ML, et al. Immunological effects of adjuvants in subsets of antigen presenting cells of cancer patients undergoing chemotherapy. J Transl Med. 2020;18:34. 
104. Arvin AM, Fink K, Schmid MA, Cathcart A, Spreafico R, Havenar-Daughton C. A perspective on potential antibody-dependent enhancement of SARS-CoV2. Nature. 2020;584:353-63.

105. Katzelnick LC, Gresh L. Antibody-dependent enhancement of severe dengue disease in humans. Science. 2017;358:929-32.

106. Smatti MK, Al Thani AA, Yassine HM. Viral-induced enhanced disease illness. Front Microbiol. 2018;9:2991.

107. Laczkó D, Hogan MJ, Toulmin SA, Hicks P, Lederer K, Gaudette BT, Castaño $D$, Amanat F, Muramatsu H, Oguin TH 3rd, et al. A single immunization with nucleoside-modified mRNA vaccines elicits strong cellular and humoral immune responses against SARS-CoV-2 in mice. Immunity. 2020;53(4):724732.e727.

108. Liu J, Chang J, Jiang Y, Meng X, Sun T, Mao L, Xu Q, Wang M. Fast and efficient CRISPR/Cas9 genome editing in vivo enabled by bioreducible lipid and messenger RNA nanoparticles. Adv Mater. 2019:31:e1902575.

109. Lokugamage MP, Gan Z, Zurla C, Levin J, Islam FZ, Kalathoor S, Sato M, Sago CD, Santangelo PJ, Dahlman JE. Mild innate immune activation overrides efficient nanoparticle-mediated RNA delivery. Adv Mater. 2020;32:e1904905.

110. Ramishetti S, Hazan-Halevy I, Palakuri R, Chatterjee S, Naidu Gonna S, Dammes N, Freilich I, Kolik Shmuel L, Danino D, Peer D. A combinatorial library of lipid nanoparticles for RNA delivery to leukocytes. Adv Mater. 2020;32:e1906128.

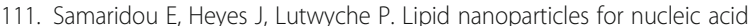
delivery: current perspectives. Adv Drug Deliv Rev. 2020;154-155:37-63.

112. Lou G, Anderluzzi G, Schmidt ST, Woods S, Gallorini S, Brazzoli M, Giusti F, Ferlenghi I, Johnson RN, Roberts CW, et al. Delivery of self-amplifying mRNA vaccines by cationic lipid nanoparticles: the impact of cationic lipid selection. J Control Release. 2020;325:370-9.

113. Tang B, Qian Y, Fang G. Development of lipid-polymer hybrid nanoparticles for improving oral absorption of enoxaparin. Pharmaceutics. 2020;12(7):607.

114. Kedmi R, Ben-Arie N, Peer D. The systemic toxicity of positively charged lipid nanoparticles and the role of toll-like receptor 4 in immune activation. Biomaterials. 2010;31:6867-75.

115. Felgner PL, Ringold GM. Cationic liposome-mediated transfection. Nature. 1989;337:387-8.

116. Haij KA, Melamed JR, Chaudhary N, Lamson NG, Ball RL, Yerneni SS, Whitehead KA. A potent branched-tail lipid nanoparticle enables multiplexed mRNA delivery and gene editing in vivo. Nano Lett. 2020;20: 5167-75.

117. Kauffman KJ, Dorkin JR, Yang JH, Heartlein MW, DeRosa F, Mir FF, Fenton OS, Anderson DG. Optimization of lipid nanoparticle formulations for mRNA delivery in vivo with fractional factorial and definitive screening designs. Nano Lett. 2015;15:7300-6.

118. Zhang G, Guo B, Wu H, Tang T, Zhang BT, Zheng L, He Y, Yang Z, Pan X, Chow $\mathrm{H}_{\text {, et }}$ al. A delivery system targeting bone formation surfaces to facilitate RNAi-based anabolic therapy. Nat Med. 2012;18:307-14.

119. Li B, Luo X, Deng B, Wang J, McComb DW, Shi Y, Gaensler KM, Tan X, Dunn $A L$, Kerlin BA, Dong Y. An orthogonal array optimization of lipid-like nanoparticles for mRNA delivery in vivo. Nano Lett. 2015;15:8099-107.

120. Suga K, Tanabe T, Tomita H, Shimanouchi T, Umakoshi H. Conformational change of single-stranded RNAs induced by liposome binding. Nucleic Acids Res. 2011;39:8891-900.

121. Cullis PR, Hope MJ. Lipid nanoparticle systems for enabling gene therapies. Mol Ther. 2017;25:1467-75.

122. Sato Y, Hashiba K, Sasaki K, Maeki M, Tokeshi M, Harashima H. Understanding structure-activity relationships of pH-sensitive cationic lipids facilitates the rational identification of promising lipid nanoparticles for delivering siRNAs in vivo. J Control Release. 2019;295:140-52.

123. Miao L, Li L, Huang Y, Delcassian D. Delivery of mRNA vaccines with heterocyclic lipids increases anti-tumor efficacy by STING-mediated immune cell activation. Nat Biotechnol. 2019;37:1174-85.

124. Le Moignic $A$, Malard $V$, Benvegnu $T$, Lemiègre $L$, Berchel $M$, Jaffrès $P A$, Baillou C, Delost M, Macedo R, Rochefort J, et al. Preclinical evaluation of mRNA trimannosylated lipopolyplexes as therapeutic cancer vaccines targeting dendritic cells. J Control Release. 2018;278:110-21.

125. Goswami R, Chatzikleanthous D, Lou G. Mannosylation of LNP results in improved potency for self-amplifying RNA (SAM) vaccines. ACS Infect Dis. 2019;5:1546-58.

126. Wang $Y$, Zhang $L, X u Z$, Miao $L$, Huang $L$. mRNA vaccine with antigenspecific checkpoint blockade induces an enhanced immune response against established melanoma. Mol Ther. 2018;26:420-34.
127. Verbeke R, Lentacker I. Broadening the message: a nanovaccine co-loaded with messenger RNA and a-GalCer induces antitumor immunity through conventional and natural killer T cells. ACS Nano. 2019;13:1655-69.

128. Pardi N, Tuyishime S, Muramatsu H, Kariko K, Mui BL, Tam YK, Madden TD, Hope MJ, Weissman D. Expression kinetics of nucleoside-modified mRNA delivered in lipid nanoparticles to mice by various routes. J Control Release. 2015;217:345-51.

129. Fan YN, Li M, Luo YL, Chen Q, Wang L, Zhang HB. Cationic lipid-assisted nanoparticles for delivery of mRNA cancer vaccine. Biomater Sci. 2018;6: 3009-18.

130. Kowalski PS, Rudra A, Miao L, Anderson DG. Delivering the messenger: advances in technologies for therapeutic mRNA delivery. Mol Ther. 2019;27:710-28.

131. Dong Y, Dorkin JR, Wang W, Chang PH, Webber MJ, Tang BC, Yang J, Abutbul-lonita I, Danino D, DeRosa F, et al. Poly(glycoamidoamine) brushes formulated nanomaterials for systemic siRNA and mRNA delivery in vivo. Nano Lett. 2016;16:842-8.

132. Patel AK, Kaczmarek JC, Bose S, Kauffman KJ, Mir F, Heartlein MW, DeRosa F, Langer R, Anderson DG. Inhaled Nanoformulated mRNA polyplexes for protein production in lung epithelium. Adv Mater. 2019;31:e1805116.

133. Kaczmarek JC, Patel AK, Kauffman KJ, Fenton OS, Webber MJ, Heartlein MW, DeRosa F, Anderson DG. Polymer-lipid nanoparticles for systemic delivery of mRNA to the lungs. Angew Chem Int Ed Engl. 2016;55:13808-12.

134. Lei C, Cui Y, Zheng L, Chow PK, Wang CH. Development of a gene/drug dual delivery system for brain tumor therapy: potent inhibition via RNA interference and synergistic effects. Biomaterials. 2013;34:7483-94.

135. Vaidyanathan S, Orr BG, Banaszak Holl MM. Role of cell membrane-vector interactions in successful gene delivery. Acc Chem Res. 2016;49:1486-93.

136. Stefan J, Kus K, Wisniewska A, Lorkowska-Zawicka B, Kaminski K, Szczubialka K, Nowakowska M, Korbut R. The antiatherogenic effect of new biocompatible cationically modified polysaccharides: chitosan and pullulan the comparison study. J Physiol Pharmacol. 2018;69(6). https://doi.org/10. 26402/jpp.2018.6.15.

137. Li M, Zhao M, Fu Y, Li Y, Gong T, Zhang Z, Sun X. Enhanced intranasal delivery of mRNA vaccine by overcoming the nasal epithelial barrier via intra- and paracellular pathways. J Control Release. 2016;228:9-19.

138. Kannan S, Kolhe P, Raykova V, Glibatec M, Kannan RM, Lieh-Lai M, Bassett D. Dynamics of cellular entry and drug delivery by dendritic polymers into human lung epithelial carcinoma cells. J Biomater Sci Polym Ed. 2004;15:311-30.

139. Chahal JS, Khan OF, Cooper CL, MCPartlan JS, Tsosie JK, Tilley LD, Sidik SM, Lourido S. Dendrimer-RNA nanoparticles generate protective immunity against lethal Ebola, H1N1 influenza, and toxoplasma gondii challenges with a single dose. Proc Natl Acad Sci U S A. 2016;113:E4133-42.

140. Chahal JS, Fang T. An RNA nanoparticle vaccine against Zika virus elicits antibody and CD8+ T cell responses in a mouse model. Sci Rep. 2017;7:252.

141. Islam MA, Xu Y, Tao W. Restoration of tumour-growth suppression in vivo via systemic nanoparticle-mediated delivery of PTEN mRNA. Nat Biomed Eng. 2018;2:850-64.

142. Yang XZ, Dou S, Sun TM, Mao CQ, Wang HX, Wang J. Systemic delivery of siRNA with cationic lipid assisted PEG-PLA nanoparticles for cancer therapy. J Control Release. 2011;156:203-11.

143. Yasar H, Biehl A, De Rossi C, Koch M, Murgia X, Loretz B, Lehr CM. Kinetics of $m R N A$ delivery and protein translation in dendritic cells using lipidcoated PLGA nanoparticles. J Nanobiotechnology. 2018;16:72.

144. Sharifnia Z, Bandehpour M, Hamishehkar H, Mosaffa N, Kazemi B, Zarghami N. In-vitro transcribed mRNA delivery using PLGA/PEI nanoparticles into human monocyte-derived dendritic cells. Iran J Pharm Res. 2019;18:1659-75.

145. Zhao W, Zhang C, Li B, Zhang X, Luo X, Zeng C, Li W, Gao M, Dong Y. Lipid polymer hybrid nanomaterials for mRNA delivery. Cell Mol Bioeng. 2018;11: 397-406.

146. Qiu Y, Man RCH, Liao Q, Kung KLK, Chow MYT, Lam JKW. Effective mRNA pulmonary delivery by dry powder formulation of PEGylated synthetic KL4 peptide. J Control Release. 2019;314:102-15.

147. Udhayakumar VK, De Beuckelaer A, McCaffrey J, McCrudden CM, Kirschman J, Vanover D, Van Hoecke L, Roose K, Deswarte K, De Geest BG, et al. Arginine-rich peptide-based mRNA nanocomplexes efficiently instigate cytotoxic T cell immunity dependent on the amphipathic organization of the peptide. Adv Healthc Mater. 2017;6(13). https://doi.org/10.1002/adhm. 201601412.

148. Hoerr I, Obst R, Rammensee HG, Jung G. In vivo application of RNA leads to induction of specific cytotoxic T lymphocytes and antibodies. Eur J Immunol. 2000;30:1-7. 
149. Stitz L, Vogel A, Schnee M, Voss D, Rauch S, Mutzke T, Ketterer T, Kramps T, Petsch B. A thermostable messenger RNA based vaccine against rabies. PLoS Negl Trop Dis. 2017;11:e0006108.

150. Scheel B, Braedel S, Probst J, Carralot JP, Wagner H, Schild H, Jung G, Rammensee HG, Pascolo S. Immunostimulating capacities of stabilized RNA molecules. Eur J Immunol. 2004;34:537-47.

151. Schlake T, Thess A, Fotin-Mleczek M, Kallen KJ. Developing mRNA-vaccine technologies. RNA Biol. 2012;9:1319-30.

152. Scheel B, Teufel R, Probst J, Carralot JP, Geginat J, Radsak M, Jarrossay D, Wagner H, Jung G, Rammensee HG, et al. Toll-like receptor-dependent activation of several human blood cell types by protamine-condensed mRNA. Eur J Immunol. 2005;35:1557-66.

153. Scheel B, Aulwurm S, Probst J, Stitz L, Hoerr I, Rammensee HG, Weller M, Pascolo $S$. Therapeutic anti-tumor immunity triggered by injections of immunostimulating single-stranded RNA. Eur J Immunol. 2006;36:2807-16.

154. Feyerabend S, Stevanovic S, Gouttefangeas C, Wernet D, Hennenlotter J, Bedke J, Dietz K, Pascolo S, Kuczyk M, Rammensee HG, Stenzl A. Novel multi-peptide vaccination in Hla-A2+ hormone sensitive patients with biochemical relapse of prostate cancer. Prostate. 2009;69:917-27.

155. Weide B, Pascolo S, Scheel B, Derhovanessian E, Pflugfelder A, Eigentler TK, Pawelec G, Hoerr I, Rammensee HG, Garbe C. Direct injection of protamineprotected mRNA: results of a phase $1 / 2$ vaccination trial in metastatic melanoma patients. J Immunother. 2009;32:498-507.

156. Westdorp H, Creemers JHA, van Oort IM, Schreibelt G, Gorris MAJ, Mehra N, Simons M, de Goede AL, van Rossum MM, Croockewit AJ, et al. Bloodderived dendritic cell vaccinations induce immune responses that correlate with clinical outcome in patients with chemo-naive castration-resistant prostate cancer. J Immunother Cancer. 2019;7:302.

157. Coolen AL, Lacroix C, Mercier-Gouy P, Delaune E, Monge C, Exposito JY, Verrier B. Poly(lactic acid) nanoparticles and cell-penetrating peptide potentiate mRNA-based vaccine expression in dendritic cells triggering their activation. Biomaterials. 2019;195:23-37.

158. Bell GD, Yang Y, Leung E, Krissansen GW. mRNA transfection by a Xentryprotamine cell-penetrating peptide is enhanced by TLR antagonist E6446. PLoS One. 2018;13:e0201464.

159. Lou B, De Koker S, Lau CYJ, Hennink WE. mRNA polyplexes with postconjugated GALA peptides efficiently target, transfect, and activate antigen presenting cells. Bioconjug Chem. 2019;30:461-75.

160. Li W, Ma L, Guo LP, Wang XL, Zhang JW, Bu ZG, Hua RH. West Nile virus infectious replicon particles generated using a packaging-restricted cell line is a safe reporter system. Sci Rep. 2017;7:3286.

161. Erasmus $J H$, Khandhar AP. An Alphavirus-derived replicon RNA vaccine induces SARS-CoV-2 neutralizing antibody and T cell responses in mice and nonhuman primates. Sci Transl Med. 2020;12:eabc9396.

162. White LJ, Sariol CA, Mattocks MD, Wahala MPBW, Yingsiwaphat V, Collier ML, Whitley J, Mikkelsen R, Rodriguez IV, Martinez MI, et al. An alphavirus vector-based tetravalent dengue vaccine induces a rapid and protective immune response in macaques that differs qualitatively from immunity induced by live virus infection. J Virol. 2013;87:3409-24.

163. Hoang-Le D, Smeenk L, Anraku I, Pijlman GP, Wang XJ, de Vrij J, Liu WJ, Le TT, Schroder WA, Khromykh AA, Suhrbier A. A Kunjin replicon vector encoding granulocyte macrophage colony-stimulating factor for intratumoral gene therapy. Gene Ther. 2009;16:190-9.

164. Lundstrom K. Replicon RNA viral vectors as vaccines. Vaccines (Basel). 2016; 4(4):39.

165. Morrison J, Plotkin S. Chapter 19 - viral vaccines: fighting viruses with vaccines. In: Viral pathogenesis; 2016. p. 253-69.

166. Fuchs JD, Frank I, Elizaga ML, Allen M, Frahm N, Kochar N, Li S, Edupuganti S, Kalams SA, Tomaras GD, et al. First-in-human evaluation of the safety and immunogenicity of a recombinant vesicular stomatitis virus human immunodeficiency virus-1 gag vaccine (HVTN 090). Open Forum Infect Dis. 2015;2:ofv082.

167. Tanaka H, Oasa S, Kinjo M, Tange K, Nakai Y, Harashima H, Akita H. Temperature and $\mathrm{pH}$ sensitivity of a stabilized self-nanoemulsion formed using an ionizable lipid-like material via an oil-to-surfactant transition. Colloids Surf B Biointerfaces. 2017;151:95-101.

168. Samsa MM, Dupuy LC, Beard CW, Six CM, Schmaljohn CS, Mason PW, Geall AJ, Ulmer JB, Yu D. Self-amplifying RNA vaccines for Venezuelan equine encephalitis virus induce robust protective immunogenicity in mice. Mol Ther. 2019;27:850-65.
169. Luisi K, Morabito KM. Development of a potent Zika virus vaccine using selfamplifying messenger. RNA. 2020;6:eaba5068.

170. Diken M, Kreiter S, Selmi A, Britten CM, Huber C, Türeci Ö, Sahin U. Selective uptake of naked vaccine RNA by dendritic cells is driven by macropinocytosis and abrogated upon DC maturation. Gene Ther. 2011;18:702-8.

171. Selmi A, Vascotto F, Kautz-Neu K, Türeci Ö, Sahin U, von Stebut E, Diken M, Kreiter S. Uptake of synthetic naked RNA by skin-resident dendritic cells via macropinocytosis allows antigen expression and induction of T-cell responses in mice. Cancer Immunol Immunother. 2016;65:1075-83.

172. Brachet J, Huez G, Hubert E. Microinjection of rabbit hemoglobin messenger RNA into amphibian oocytes and embryos. Proc Natl Acad Sci U S A. 1973;70:543-7.

173. Gallie DR. The cap and poly(A) tail function synergistically to regulate mRNA translational efficiency. Genes Dev. 1991;5:2108-16.

174. Stewart MP, Langer R. Intracellular delivery by membrane disruption: mechanisms. Strateg Concepts. 2018;118:7409-531.

175. Ringer S. Regarding the action of hydrate of soda, hydrate of ammonia, and hydrate of potash on the ventricle of the frog's heart. J Physiol. 1882;3:195202.196.

176. Lee JA. Sydney Ringer (1834-1910) and Alexis Hartmann (1898-1964). Anaesthesia. 1981;36:1115-21.

177. Probst J, Weide B, Scheel B, Pichler BJ, Hoerr I, Rammensee HG, Pascolo S. Spontaneous cellular uptake of exogenous messenger RNA in vivo is nucleic acid-specific, saturable and ion dependent. Gene Ther. 2007;14:1175-80.

178. Sahin U, Derhovanessian E, Miller M, Kloke BP, Simon P, Löwer M, Bukur V, Tadmor AD, Luxemburger U, Schrörs B, et al. Personalized RNA mutanome vaccines mobilize poly-specific therapeutic immunity against cancer. Nature. 2017;547:222-6.

179. Edwards DK, Jasny E, Yoon H, Horscroft N, Schanen B, Geter T, Fotin-Mleczek $M$, Petsch B, Wittman V. Adjuvant effects of a sequence-engineered mRNA vaccine: translational profiling demonstrates similar human and murine innate response. J Transl Med. 2017;15:1.

180. Kreiter S, Diken M, Selmi A, Diekmann J, Attig S, Hüsemann Y, Koslowski M, Huber C, Türeci Ö, Sahin U. FLT3 ligand enhances the cancer therapeutic potency of naked RNA vaccines. Cancer Res. 2011;71:6132-42.

181. Van Lint S, Goyvaerts C, Maenhout S, Goethals L, Disy A, Benteyn D, Pen J, Bonehill A, Heirman C, Breckpot K, Thielemans K. Preclinical evaluation of TriMix and antigen mRNA-based antitumor therapy. Cancer Res. 2012;72:1661-71.

182. Hewitt SL, Bailey D, Zielinski J, Apte A, Musenge F. Intratumoral interleukin12 mRNA therapy promotes $\mathrm{TH} 1$ transformation of the tumor microenvironment. Clin Cancer Res. 2020;26:6284-98.

183. Van der Jeught $K$, Joe PT, Bialkowski L, Heirman C, Daszkiewicz L, Liechtenstein T, Escors D, Thielemans K, Breckpot K. Intratumoral administration of mRNA encoding a fusokine consisting of IFN- $\beta$ and the ectodomain of the TGF- $\beta$ receptor $\|$ potentiates antitumor immunity. Oncotarget. 2014;5:10100-13.

184. Van Lint S, Renmans D, Broos K, Goethals L, Maenhout S, Benteyn D, Goyvaerts C, Du Four S, Van der Jeught K, Bialkowski L, et al. Intratumoral delivery of TriMix mRNA results in T-cell activation by cross-presenting dendritic cells. Cancer Immunol Res. 2016;4:146-56.

185. Eisenbarth SC. Dendritic cell subsets in T cell programming: location dictates function. Nat Rev Immunol. 2019;19:89-103.

186. Kambayashi T, Laufer TM. Atypical MHC class II-expressing antigenpresenting cells: can anything replace a dendritic cell? Nat Rev Immunol. 2014;14:719-30

187. Ding Y, Guo Z, Liu Y, Li X, Zhang Q, Xu X, Gu Y, Zhang Y, Zhao D, Cao X. The lectin Siglec-G inhibits dendritic cell cross-presentation by impairing MHC class I-peptide complex formation. Nat Immunol. 2016;17:1167-75.

188. Qiao J, Liu Z, Dong C, Luan Y, Zhang A, Moore C, Fu K, Peng J, Wang Y, Ren Z, et al. Targeting tumors with IL-10 prevents dendritic cell-mediated CD8(+ ) T cell apoptosis. Cancer Cell. 2019;35:901-915.e904.

189. Inaba K, Metlay JP, Crowley MT, Steinman RM. Dendritic cells pulsed with protein antigens in vitro can prime antigen-specific, MHC-restricted T cells in situ. J Exp Med. 1990;172:631-40.

190. De Temmerman ML, Dewitte H, Vandenbroucke RE, Lucas B, Libert C, Demeester J, De Smedt SC, Lentacker I, Rejman J. mRNA-Lipoplex loaded microbubble contrast agents for ultrasound-assisted transfection of dendritic cells. Biomaterials. 2011:32:9128-35.

191. Tuyaerts S, Noppe SM, Corthals J, Breckpot K, Heirman C, De Greef C, Van Riet I, Thielemans K. Generation of large numbers of dendritic cells in a closed system using cell factories. J Immunol Methods. 2002;264:135-51. 
192. Ahmed R, Sayegh N, Graciotti M, Kandalaft LE. Electroporation as a method of choice to generate genetically modified dendritic cell cancer vaccines. Curr Opin Biotechnol. 2020;65:142-55.

193. Hiasa M, Abe M, Nakano A, Oda A, Amou H, Kido S, Takeuchi K, Kagawa K, Yata K, Hashimoto T, et al. GM-CSF and IL-4 induce dendritic cell differentiation and disrupt osteoclastogenesis through M-CSF receptor shedding by up-regulation of TNF-alpha converting enzyme (TACE). Blood. 2009;114:4517-26.

194. Fernández-Delgado I, Calzada-Fraile D. Immune regulation by dendritic cell extracellular vesicles in cancer immunotherapy and vaccines. Cancers (Basel). 2020;12.

195. Carreno BM, Becker-Hapak M, Huang A, Chan M, Alyasiry A, Lie WR, Aft RL, Cornelius LA, Trinkaus KM, Linette GP. IL-12p70-producing patient DC vaccine elicits Tc1-polarized immunity. J Clin Invest. 2013;123:3383-94

196. Napolitani G, Rinaldi A, Bertoni F, Sallusto F, Lanzavecchia A. Selected tolllike receptor agonist combinations synergistically trigger a $T$ helper type 1 polarizing program in dendritic cells. Nat Immunol. 2005;6:769-76.

197. Dewitte H, Van Lint S, Heirman C, Thielemans K, De Smedt SC, Breckpot K, Lentacker I. The potential of antigen and TriMix sonoporation using mRNAloaded microbubbles for ultrasound-triggered cancer immunotherapy. J Control Release. 2014;194:28-36.

198. Kranz LM, Diken M, Haas H, Kreiter S, Loquai C, Reuter KC, Meng M, Fritz D, Vascotto F, Hefesha $H$, et al. Systemic RNA delivery to dendritic cells exploits antiviral defence for cancer immunotherapy. Nature. 2016;534:396-401.

199. Gandhi RT, Kwon DS, Macklin EA, Shopis JR, McLean AP, McBrine N, Flynn T, Peter L, Sbrolla A, Kaufmann DE, et al. Immunization of HIV-1-infected persons with autologous dendritic cells transfected with mRNA encoding HIV-1 gag and Nef: results of a randomized, placebo-controlled clinical trial. J Acquir Immune Defic Syndr. 2016;71:246-53.

200. Jacobson JM, Routy JP, Welles S, DeBenedette M, Tcherepanova I, Angel JB, Asmuth DM, Stein DK, Baril JG, McKellar M, et al. Dendritic cell immunotherapy for HIV-1 infection using autologous HIV-1 RNA: a randomized, double-blind, placebo-controlled clinical trial. J Acquir Immune Defic Syndr. 2016;72:31-8.

201. Gay CL, DeBenedette MA, Tcherepanova IY, Gamble A, Lewis WE, Cope AB, Kuruc JD, McGee KS, Kearney MF, Coffin JM, et al. Immunogenicity of AGS 004 dendritic cell therapy in patients treated during acute HIV infection. AIDS Res Hum Retrovir. 2018:34:111-22

202. Derdelinckx J, Mansilla MJ, De Laere M, Lee WP, Navarro-Barriuso J, Wens I, Nkansah I, Daans J, De Reu H, Jolanta Keliris A, et al. Clinical and immunological control of experimental autoimmune encephalomyelitis by tolerogenic dendritic cells loaded with MOG-encoding mRNA. J Neuroinflammation. 2019;16:167.

203. Stewart MP, Sharei A, Ding X, Sahay G, Langer $R$, Jensen KF. In vitro and ex vivo strategies for intracellular delivery. Nature. 2016;538:183-92.

204. Derdelinckx J, Berneman ZN, Cools N. GMP-grade mRNA electroporation of dendritic cells for clinical use. Methods Mol Biol. 2016;1428:139-50.

205. Boczkowski D, Nair SK, Snyder D, Gilboa E. Dendritic cells pulsed with RNA are potent antigen-presenting cells in vitro and in vivo. J Exp Med. 1996; 184:465-72.

206. De Keersmaecker B, Heirman C, Corthals J, Empsen C, van Grunsven LA Allard SD, Pen J, Lacor P, Thielemans K, Aerts JL. The combination of 4-1BBL and CD40L strongly enhances the capacity of dendritic cells to stimulate HIV-specific T cell responses. J Leukoc Biol. 2011;89:989-99.

207. Aerts-Toegaert C, Heirman C, Tuyaerts S, Corthals J, Aerts JL, Bonehill A, Thielemans K, Breckpot K. CD83 expression on dendritic cells and T cells: correlation with effective immune responses. Eur J Immunol. 2007;37:68695.

208. Dannull J, Nair S, Su Z, Boczkowski D, DeBeck C, Yang B, Gilboa E, Vieweg J. Enhancing the immunostimulatory function of dendritic cells by transfection with mRNA encoding OX40 ligand. Blood. 2005;105:3206-13.

209. Met O, Balslev E, Flyger H, Svane IM. High immunogenic potential of p53 mRNA-transfected dendritic cells in patients with primary breast cancer. Breast Cancer Res Treat. 2011;125:395-406.

210. Do ASS, Amano T, Edwards LA, Zhang L, De Peralta-Venturina M, Yu JS. CD133 mRNA-loaded dendritic cell vaccination abrogates glioma stem cell propagation in humanized glioblastoma mouse model. Mol Ther Oncolytics. 2020;18:295-303.

211. Minkis K, Kavanagh DG, Alter G, Bogunovic D, O'Neill D, Adams S, Pavlick A, Walker BD, Brockman MA, Gandhi RT, Bhardwaj N. Type 2 bias of T cells expanded from the blood of melanoma patients switched to type 1 by IL12p70 mRNA-transfected dendritic cells. Cancer Res. 2008;68:9441-50.

212. Bontkes HJ, Kramer D, Ruizendaal JJ, Meijer CJ, Hooijberg E. Tumor associated antigen and interleukin-12 mRNA transfected dendritic cells enhance effector function of natural killer cells and antigen specific T-cells. Clin Immunol. 2008;127:375-84

213. Coosemans A, Tuyaerts S, Morias K, Corthals J, Heirman C, Thielemans K, Van Gool SW, Vergote I, Amant F. mRNA electroporation of dendritic cells with WT1, survivin, and TriMix (a mixture of caTLR4, CD40L, and CD70). Methods Mol Biol. 2016;1428:277-83.

214. Bonehill A, Tuyaerts S, Van Nuffel AM, Heirman C, Bos TJ, Fostier K, Neyns B, Thielemans K. Enhancing the T-cell stimulatory capacity of human dendritic cells by co-electroporation with CD40L, CD70 and constitutively active TLR4 encoding mRNA. Mol Ther. 2008;16:1170-80.

215. Pen JJ, De Keersmaecker B, Maenhout SK, Van Nuffel AM, Heirman C, Corthals J, Escors D, Bonehill A, Thielemans K, Breckpot K, Aerts JL. Modulation of regulatory $T$ cell function by monocyte-derived dendritic cells matured through electroporation with mRNA encoding CD40 ligand, constitutively active TLR4, and CD70. J Immunol. 2013;191:1976-83.

216. Wilgenhof S, Van Nuffel AM, Benteyn D, Corthals J, Aerts C, Heirman C, Van Riet I, Bonehill A, Thielemans K, Neyns B. A phase IB study on intravenous synthetic mRNA electroporated dendritic cell immunotherapy in pretreated advanced melanoma patients. Ann Oncol. 2013;24:2686-93.

217. Zeng C, Hou X, Yan J, Zhang C, Li W, Zhao W, Du S, Dong Y. Leveraging mRNA sequences and nanoparticles to deliver SARS-CoV-2 antigens in vivo. Adv Mater. 2020:32:e2004452

218. Lu J, Lu G, Tan S, Xia J, Xiong H, Yu X. A COVID-19 mRNA vaccine encoding SARS-CoV-2 virus-like particles induces a strong antiviral-like immune response in mice. Cell Res. 2020;30:936-9.

219. Zhang NN, Li XF, Deng YQ, Zhao H, Huang YJ, Yang G, Huang WJ, Gao P, Zhou C, Zhang RR, et al. A thermostable mRNA vaccine against COVID-19. Cell. 2020;182:1271-1283.e1216.

220. Mulligan MJ, Lyke KE, Kitchin N, Absalon J. Phase I/II study of COVID-19 RNA vaccine BNT162b1 in adults. Nature. 2020;586:589-93.

221. Mulligan MJ, Lyke KE, Kitchin N, Absalon J. Phase 1/2 study of COVID-19 RNA vaccine BNT162b1 in adults. Nature. 2020;586:589-93.

222. Sahin U, Muik A. COVID-19 vaccine BNT162b1 elicits human antibody and $\mathrm{T}(\mathrm{H}) 1 \mathrm{~T}$ cell responses. Nature. 2020;586:594-9.

223. Abbasi J. COVID-19 and mRNA vaccines-first large test for a new approach. JAMA. 2020;324:1125-7.

224. Maruggi G, Chiarot E, Giovani C, Buccato S, Bonacci S, Frigimelica E, Margarit I, Geall A, Bensi G, Maione D. Immunogenicity and protective efficacy induced by self-amplifying mRNA vaccines encoding bacterial antigens. Vaccine. 2017:35:361-8.

225. Baeza Garcia A, Siu E, Sun T, Exler V, Brito L, Hekele A, Otten G, Augustijn K, Janse CJ, Ulmer JB, et al. Neutralization of the plasmodium-encoded MIF ortholog confers protective immunity against malaria infection. Nat Commun. 2018:9:2714.

\section{Publisher's Note}

Springer Nature remains neutral with regard to jurisdictional claims in published maps and institutional affiliations.

Ready to submit your research? Choose BMC and benefit from:

- fast, convenient online submission

- thorough peer review by experienced researchers in your field

- rapid publication on acceptance

- support for research data, including large and complex data types

- gold Open Access which fosters wider collaboration and increased citations

- maximum visibility for your research: over $100 \mathrm{M}$ website views per year

At $\mathrm{BMC}$, research is always in progress.

Learn more biomedcentral.com/submissions 